\title{
Oak seedling survival and growth along resource gradients in Mediterranean forests: implications for regeneration in current and future environmental scenarios
}

\author{
L. Gómez-Aparicio, I. M. Pérez-Ramos, I. Mendoza, L. Matías, J. L. Quero, J. Castro, R. Zamora \\ and T. Marañón
}

L. Gómez-Aparicio (lorenag@irnase.csic.es), I. M. Pérez-Ramos and T. Marañón, Inst. de Recursos Naturales y Agrobiología (IRNAS, CSIC), PO Box 1052, ES-41080 Seville, Spain. - I. Mendoza, L. Matías, J. L. Quero, J. Castro and R. Zamora, Dpto. de Ecología, Facultad de Ciencias, Univ. de Granada, ES-18071 Granada, Spain.

\begin{abstract}
Understanding seedling performance across resource gradients is crucial for defining the regeneration niche of plant species under current environmental conditions and for predicting potential changes under a global change scenario. A 2-year field experiment was conducted to determine how seedling survival and growth of two evergreen and two deciduous Quercus species vary along gradients of light and soil properties in two Mediterranean forests with contrasting soils and climatic conditions. Half the seedlings were subjected to an irrigation treatment during the first year to quantify the effects on performance of an alteration in the summer drought intensity. Linear and non-linear models were parameterized and compared to identify major resources controlling seedling performance. We found both site-specific and general patterns of regeneration. Strong site-specificity was found in the identity of the best predictors of seedling survival: survival decreased linearly with increasing light (i.e. increasing desiccation risk) in the drier site, whereas it decreased logistically with increasing spring soil water content (i.e. increasing waterlogging risk) in the wetter site. We found strong empirical support for multiple resource limitation at the drier site, the response to light being modulated by the availability of soil resources (water and P). Evidence for regeneration niche partitioning among Quercus species was only found at the wetter site. However, at both sites Quercus species shared the same response to summer drought allevation through water addition: increased first-year survival but not final survival (i.e. after two years). This suggests that extremely dry summers (i.e. the second summer in the experiment) can cancel out the positive effects of previous wetter summers. Therefore, an increase in the intensity and frequency of summer drought with climate change might cause a double negative impact on Quercus regeneration, due to a general reduction in survival probability and the annulment of the positive effects of (infrequent) 'wet' years. Overall, results presented in this study are a major step towards the development of a mechanistic model of Mediterranean forest dynamics that incorporates the idiosyncrasies and generalities of tree regeneration in these systems, and that allow simulation and prediction of the ecological consequences of resource level alterations due to global change.
\end{abstract}

In a time of global change, a major concern facing ecologists is to determine the extent to which the alteration of environmental conditions will affect structure and dynamics of plant communities (Vitousek 1994, Chapin et al. 2001, Peñuelas et al. 2004). Changes in temperature, rainfall patterns, biogeochemical cycles and land use have already been recorded worldwide and are predicted to intensify in the future (Canadell et al. 2006). Altogether, these changes entail the simultaneous alteration in the average levels and spatio-temporal variability of the basic resources for plant regeneration, mainly light, water and nutrients. Therefore, understanding species-specific responses to different resource levels is crucial for accurate predictions on global change effects, improving our ability to manage and conserve plant communities in current and future environmental scenarios.
Plants are especially vulnerable to environmental constraints during early life-stages (Harper 1977, Kitajima and Fenner 2000). Consequently, seedlings and saplings are particularly suitable for exploring species responses to changing resource levels. The common way of analysing the relationship between resources and plant performance is through controlled garden and greenhouse experiments, in which seedlings of different species are subjected to various levels of water, light, or nutrients (Espelta et al. 2005, Quero et al. 2006, Sánchez-Gómez et al. 2006). Although the value of this approach is unquestionable, it only allows the effect of a low number of resources and levels to be evaluated at once. Natural regeneration, however, takes place in a much more complex scenario. The regeneration niche (sensu Grubb 1977) is a multidimensional space where many abiotic and biotic factors act simultaneously 
and interactively, these interactions being sometimes even more important that the main effects (Ibañez and Shupp 2001, Gómez 2004). Studies that explore seedling performance through environmental gradients under field conditions are necessary to discern the ranking and interactions among factors determining spatio-temporal patterns of plant recruitment.

Mediterranean-type ecosystems are predicted to be among the most vulnerable to climate change due to an intensification of their already limiting conditions for plant regeneration (Schröter et al. 2005, Christensen et al. 2007). Global climate models predict increasing aridity in the Mediterranean climate (i.e. higher temperatures, lower rainfall, and greater potential evapotranspiration), as well as greater frequency of extreme weather conditions (Peñuelas et al. 2004, Christensen et al. 2007). Therefore, summer drought, a major cause of mortality of Mediterranean woody species during early life stages (Herrera et al. 1994, Gómez-Aparicio et al. 2005), would be expected to increase in severity. On the other hand, global change processes (e.g. increase in forest fires and erosion, greater nutrient mobilization and emission) could drive changes in the nutrient supply in Mediterranean areas, characterized by nutrient-poor soils, especially in P (Witkowski et al. 1990, Sardans et al. 2004, 2005). However, since most regeneration studies focus on the role of water and light more than on nutrients, scant information is available on how Mediterranean tree species respond to natural gradients of nutrients. This information is especially valuable not only to understand the effects of altered biogeochemical cycles on seedling establishment, but because changes in nutrient levels might alter the species ability to survive under limiting conditions of water and light (Coomes and Grubb 2000). For example, Kobe et al. (1995) showed that in temperate forests of North America, Acer saccharum and Fraxinus americana saplings were more shade-tolerant in calcareous soils (with high $\mathrm{pH}$ and $\mathrm{Ca}$ levels) than in acidic soils. These types of multiple resource limitation have rarely been explored in Mediterranean forests.

In this study, we present the results of a 2-year field experiment conducted to determine how seedling survival and growth of four late-successional Quercus species, two evergreen (Quercus ilex subsp. ballota and Quercus suber) and two deciduous (Quercus pyrenaica and Quercus canariensis), vary along natural gradients of light, soil water content, nutrients and soil compaction in two Mediterranean forests with contrasting soils and climatic conditions. Moreover, for half of the seedlings we artificially varied the natural levels of water available during the summer in order to quantify how current resource-performance relationships could be affected by an alteration in the intensity of summer drought. Specifically, we calibrated linear and non-linear regression models of seedling survival and growth in order to answer the following questions: 1) what are the main resources and the functional relationships explaining patterns of Quercus seedling survival and growth in Mediterranean forests? 2) Do coexisting Quercus species differ in their response to resource gradients? 3) What are the implications of a variation in the intensity of summer drought for the magnitude of seedling performance and its distribution along resource gradients? By answering these questions, we seek to gain insights into patterns of Quercus seedling dynamics under current environmental conditions and discuss potential implications for regeneration under a global change scenario.

\section{Material and methods}

\section{Study sites and species}

The field experiment was conducted in two protected areas of southern Spain: Sierra Nevada National Park in the southeast and Alcornocales Natural Park in the southwest, near the Strait of Gibraltar. The two study sites vary in altitude, climate, and soil conditions (Table 1). The climate at both sites is Mediterranean-type, characterized by hot, dry summers. Mean annual rainfall is much lower in Sierra Nevada than in Alcornocales. However, summer rainfall (June-September) is very low and sporadic at both sites. Temperatures in Alcornocales are milder than in Sierra Nevada due to the lower altitude and the proximity of the Mediterranean Sea (Table 1). The two study years (2004 and 2005) had contrasting weather conditions. The 2004 was an average year in terms of both annual rainfall (750.0 $\mathrm{mm}$ in Sierra Nevada, $1464.1 \mathrm{~mm}$ in Alcornocales) and summer rainfall $(28.5 \mathrm{~mm}$ and $4.8 \mathrm{~mm}$, respectively). However, 2005 was an extremely dry year at both study sites $(394.3 \mathrm{~mm}$ annual rainfall and $8 \mathrm{~mm}$ summer rainfall in Sierra Nevada, $807.7 \mathrm{~mm}$ annual rainfall and $0 \mathrm{~mm}$ summer rainfall in Alcornocales; all values within the first quartile for the series 1990-2005).

The dominant bedrock is limestone in Sierra Nevada and Oligo-Miocene sandstone in Alcornocales, giving rise to basic loamy soils and acidic sandy soils, respectively. The forest site in Sierra Nevada encompasses a mosaic of mixed pine-oak forest (mainly Pinus sylvestris and $Q$. ilex, with

Table 1. Summary of the main characteristics of the two study sites. Mean \pm SD are shown.

\begin{tabular}{|c|c|c|}
\hline & \multicolumn{2}{|c|}{ Study sites } \\
\hline & Sierra Nevada & Alcornocales \\
\hline Longitude & $35^{\circ} 55^{\prime} 00^{\prime \prime} \mathrm{N}$ & $36^{\circ} 31^{\prime} 54^{\prime \prime} \mathrm{N}$ \\
\hline Latitude & $3^{\circ} 02^{\prime} 00^{\prime \prime} \mathrm{W}$ & $5^{\circ} 34^{\prime} 29^{\prime \prime} \mathrm{W}$ \\
\hline Altitude (m a.s.l.) & 1650 & 530 \\
\hline \multicolumn{3}{|l|}{ Rainfall $(\mathrm{mm})^{*}$} \\
\hline annual & $840.2 \pm 350.7$ & $1419.3 \pm 473.2$ \\
\hline summer & $42.9 \pm 34.4$ & $19.1 \pm \overline{45} .0$ \\
\hline \multicolumn{3}{|l|}{ Temperature $\left({ }^{\circ} \mathrm{C}\right)^{*}$} \\
\hline mean annual & $12.0 \pm 7.9$ & $14.1 \pm 7.1$ \\
\hline & $-0.9 \pm 4.3$ & $6.2 \pm 4.5$ \\
\hline mean maximum July & $30.0 \pm 8.7$ & $26.6 \pm 5.2$ \\
\hline Bedrock & limestone & sandstone \\
\hline \multicolumn{3}{|l|}{ Vegetation $\dagger$} \\
\hline \multirow[t]{3}{*}{ tree species } & Pinus sylvestris & Quercus suber \\
\hline & Quercus ilex & Quercus canariensis \\
\hline & Quercus pyrenaica & Quercus pyrenaica \\
\hline \multirow[t]{3}{*}{ shrub species } & Salvia lavandulifolia & Phillyrea latifolia \\
\hline & Crataegus monogyna & Teline linifolia \\
\hline & Genista cinerea & Pistacia lentiscus \\
\hline
\end{tabular}

*average for the series 1990-2005; data from meteorological stations located at each study site.

fonly the most abundant woody species at each site are listed. 
Q. pyrenaica and Acer opalus subsp. granatense as accompanying species), intermingled with shrubs and open areas covered by sparse herbaceous vegetation. The forest site in Alcornocales is a mixed oak forest co-dominated by $Q$. suber and $Q$. canariensis, with a rich and dense shrubby understorey (Quilchano et al. 2008). Q. suber has the wider distribution range at the landscape scale, whereas Q. canariensis is more abundant near streams (Urbieta et al. in press). Patches of $Q$. pyrenaica are locally abundant at higher altitudes $(>900 \mathrm{~m})$. The four oak species of study (Q. ilex, Q. pyrenaica, Q. suber and Q. canariensis) are major components of late-successional forest communities in the West Mediterranean Basin. At broad regional scales, evergreen oaks tend to occupy drier and poorer soils than do deciduous oaks, but two types of oak have overlapping ranges and they coexist in many habitats (Blanco et al. 2005).

\section{Experimental design}

Acorns of Quercus ilex, Q. suber and Q. canariensis were collected from several trees in the surroundings of the study sites during the fruiting season (October-December) in 2003, and stored on a moist substrate at $2-4^{\circ} \mathrm{C}$ until used. Acorns of $Q$. pyrenaica were collected from a third mountain range also in southern Spain (Sierra de Cardeña) due to the scarce fruit production of the species at the two study sites. The same pool of Q. pyrenaica acorns was used for sowing in Sierra Nevada and Alcornocales, which allowed us to use this species to explore among-site variability in specific responses to environmental gradients.

In January 2004, acorns from the four species were sown in wire cages $(25 \times 25 \times 25 \mathrm{~cm}, 1.3 \mathrm{~cm}$ mesh size $)$ to exclude seed predators. Sowing points were selected to cover the widest possible range of light and soil conditions at each site, from open spaces ( $>90 \%$ full sunlight) to shady microhabitats $(<10 \%$ full sunlight) under the canopy of tree and shrub species (see list of species in Table 1). In Sierra Nevada, 90 sowing points were selected, each sowing point consisting of two cages with five acorns of either Q. ilex or Q. pyrenaica ( $\mathrm{n}=180$ cages total). In Alcornocales, 120 sowing points were selected, each sowing point consisting of two cages with five acorns of either $Q$. suber or Q. canariensis $(\mathrm{n}=240$ cages total). Two acorns of Q. pyrenaica were also sown in each of the 240 cages in Alcornocales. Acorns were sown at $1 \mathrm{~cm}$ depth and separated $5 \mathrm{~cm}$ from each other. The total number of acorns sown in the experiment was 450 of Q. ilex and 450 of Q. pyrenaica in Sierra Nevada, and 600 of Q. suber, 600 of Q. canariensis, and 480 of Q. pyrenaica in Alcornocales. Mean acorn mass $( \pm \mathrm{SD})$ was $3.5 \pm 1.5 \mathrm{~g}$ for $Q$. ilex, $5.2 \pm$ $1.2 \mathrm{~g}$ for $Q$. pyrenaica, $4.4 \pm 1.6 \mathrm{~g}$ for $Q$. suber, and $4.5 \pm$ $1.4 \mathrm{~g}$ for $Q$. canariensis.

Half of the cages were subjected to an irrigation treatment during the summer months of the first year of the experiment (90 days, June-September 2004), whereas the other half was used as control. Irrigation consisted of adding ca $30 \mathrm{l} \mathrm{m}^{-2}$ at around two weeks intervals. The irrigation treatment simulated the 'wet', stormy summers that sporadically occur in Mediterranean mountains, and that are related to peaks of recruitment of tree species due to increased seedling survival (Gómez-Aparicio et al. 2005).

\section{Characterization of the abiotic environment}

We characterized the aboveground (light availability) and belowground (soil water content, textural and chemical characteristics and compaction) environment for each of the 420 cages of the experiment. Light availability was quantified by hemispherical photography. Photographs were taken at the seedling level using a horizontally-levelled digital camera and aimed at the zenith, using a fish-eye lens of $180^{\circ}$ field of view. The images were analysed using Hemiview canopy analysis software ver. 2.1. The software estimates Direct and Indirect site factors (DSF and ISF), which are defined as the proportion of direct and diffuse radiation, respectively, for clear sky conditions at our study site (Rich 1990). Site factors range from 1 (open sky) to 0 (complete obstruction). Direct and indirect site factors were combined into a global site factor (GSF) using weights that represent the proportion of diffuse vs direct light at our study site (10\% ISF vs $90 \%$ DSF).

Volumetric water content of the topsoil (12 cm depth) was measured using a time - domain reflectometer. Measurements were taken every two months during spring and summer of the first year of the experiment (i.e. four times during March-September 2004). The first two measurements were averaged to calculate, for each cage, the volumetric soil water content in the spring rainy season ( $\left.\mathrm{VWC}_{\text {spring }}\right)$, whereas the two last measurements were averaged to calculate the volumetric soil water content in summer $\left(\mathrm{VWC}_{\text {summer }}\right)$, the time of maximum soil dryness. Since rainfall in 2004 was close to the average for the study sites, we considered these measurements to be representative of the average soil water content available for seedlings at each sowing point and season.

To analyse the textural and chemical soil characteristics, we sampled the upper $20 \mathrm{~cm}$ of the soil using an auger. Samples were dried and sieved and the $<2-\mathrm{mm}$ fraction was analysed for standard physico-chemical properties (Anon. 1994). Nine soil properties were determined: $\mathrm{pH}$ (with a $\mathrm{pH}$ meter), percentage of organic matter (OM, combustion at $540^{\circ} \mathrm{C}$ ), total $\mathrm{N}$ (TN, Kjeldahl method), $\mathrm{C}: \mathrm{N}$ ratio (estimated as $(\mathrm{OM} / 2) / \mathrm{TN}$, therefore assuming a OM/C relationship of 2; Nelson and Sommers 1982), available P (Olsen method), available K (inductively plasma atomic emission spectrometry), and percentages of sand, clay and silt (Bouyoucos hydrometer method). Among the three soil-texture fractions, the percentage of sand was chosen to be included in the statistical analyses as a measurement of texture characteristics.

Soil compaction was measured using a penetrometer that provides a value of resistance to penetration at every $\mathrm{cm}$ in depth. The result for each point sampled is a profile describing the variation of soil compaction with depth. From these profiles, we derived two variables that can affect rooting penetration and consequently seedling performance: the maximum compaction in the profile, and the maximum depth at which compaction was measured, which provides an estimation of soil depth. 


\section{Seedling monitoring}

Each seedling that emerged in the cages during the spring of 2004 was individually tagged and its survival was monitored periodically until the end of the second summer (September 2005). The total number of seedlings tagged was: 217 for Q. ilex (48\% emergence) and 250 for Q. pyrenaica $(54 \%$ emergence) in Sierra Nevada; 317 for Q. suber $(54 \%$ emergence), 224 for Q. canariensis (38\% emergence) and 220 for Q. pyrenaica (49\% emergence) in Alcornocales. Detailed analyses of seed germination and emergence patterns are the object of complementary studies (Mendoza et al. unpubl., Urbieta et al. unpubl.). At the end of the experiment (two years), surviving seedlings were collected and then separated into root, stem and leaves in the laboratory, where all parts were oven-dried at $80^{\circ} \mathrm{C}$ for $48 \mathrm{~h}$ and weighed. From these data, three response variables were calculated: 1) first-year survival (i.e. after one growing season), calculated as the percentage of the seedlings alive in each cage at the end of the first summer (September 2004); 2) cumulative final survival (i.e. after two growing seasons), calculated as the percentage of the seedlings alive in each cage in September 2005; and 3) final aboveground biomass, calculated as the sum of the biomass of stem and leaves at the end of the study. Due to the difficulties of excavating roots of Quercus species without losing a significant part of the root system, we decided not to consider root biomass for the calculation of the final biomass. By distinguishing between first-year survival (when the irrigation treatment was applied) and cumulative final survival (after a summer with irrigation followed by a summer without it) we sought to determine the immediate and delayed consequences of water addition for seedling survival.

\section{Data analyses}

\section{Characterization of the abiotic environment}

Mean $( \pm S D)$, and range values were calculated for the 12 abiotic variables used as predictors in the models of seedling performance (see below) separately for each of the two study sites (see variable list in Table 2). Differences among the two study sites in abiotic conditions were tested using one-way ANOVAs. Correlations among abiotic variables were explored by Pearson's correlation analyses. The criterion false discovery rate (FDR, the expected proportion of tests erroneously declared as significant) was applied to control the inflation of type I error derived from repeated testing. The FDR was controlled at the 5\% level using a standard step-up procedure (García 2004).

\section{Models of seedling survival and growth}

Each of the three response variables (first-year survival, final survival, and final aboveground biomass) was modelled independently as a function of each of the 12 abiotic factors considered in the study. Means of survival and growth for seedlings within the same cage were analysed in the models (instead of individual seedling data) to avoid pseudoreplication. All models were fitted individually for each combination of species and site. We tested three alternative formulations of species-specific models that encapsulated different responses of seedling performance to abiotic factors: a linear response (linear model), an exponential response (exponential model), and a saturating response (logistic model) (equations in Appendix 2, 3 and 4). To test the significance of the effect of an abiotic factor on seedling performance, the best of the three models was compared to a fourth model (the null model) which assumes constant performance over measured variation in the abiotic factor. We also tested two additional models: a lognormal model, in which seedling performance is allowed to reach a maximum at some level of the abiotic factor, and a Michaelis-Menten model, a function commonly used to model sapling growth (Pacala et al. 1994, Kobe et al. 1995). Since these two models were never the best fit, either for survival or growth, results are not given for simplicity.

The modelling process had three steps. First, models were run for each abiotic factor independently (watered and control seedlings pooled). Second, to test for multiple resource limitation, bivariate models were fit using those abiotic factors that had an effect on seedling performance

Table 2. Mean, standard deviation, and range (in brackets) of the 12 abiotic predictors of seedling performance measured at the two study sites. Results of the one-way ANOVAs comparing among-site differences for each factor are also given.

\begin{tabular}{|c|c|c|c|c|}
\hline \multirow{2}{*}{ Abiotic factor } & \multicolumn{2}{|c|}{ Study sites } & \multirow[t]{2}{*}{$\mathrm{F}$} & \multirow[t]{2}{*}{$\mathrm{p}$} \\
\hline & Sierra Nevada & Alcornocales & & \\
\hline GSF & $0.54 \pm 0.28[0.13-0.91]$ & $0.33 \pm 0.24[0.08-0.92]$ & 28.46 & $<0.0001$ \\
\hline VWC $C_{\text {spring }}(\%)$ & $21.75 \pm 5.97[12.50-36.00]$ & $54.42 \pm 24.71[24.50-100]$ & 70.65 & $<0.0001$ \\
\hline $\mathrm{VWC}_{\text {summer }}(\%)$ & $7.03 \pm 2.72[2.50-12.50]$ & $9.02 \pm 3.27[4.00-16.00]$ & 11.38 & 0.001 \\
\hline $\mathrm{pH}$ & $7.89 \pm 0.29[6.80-8.40]$ & $6.19 \pm 0.57[5.39-8.30]$ & 304.44 & $<0.0001$ \\
\hline OM (\%) & $4.62 \pm 2.78[1.39-15.89]$ & $10.61 \pm 3.74[4.80-20.60]$ & 70.77 & $<0.0001$ \\
\hline $\mathrm{TN}$ & $0.27 \pm 0.11[0.12-0.67]$ & $0.33 \pm 0.12[0.12-0.75]$ & 19.29 & $<0.0001$ \\
\hline $\mathrm{C}: \mathrm{N}$ & $8.19 \pm 2.63[4.06-18.17]$ & $16.15 \pm 2.32[9.70-22.09]$ & 254.62 & $<0.0001$ \\
\hline $\mathrm{P}(\mathrm{ppm})$ & $4.57 \pm 3.11[1.00-19.00]$ & $3.13 \pm 2.61[0-14.90]$ & 9.50 & 0.002 \\
\hline $\mathrm{K}(\mathrm{ppm})$ & $118.76 \pm 49.41[26.00-245.00]$ & $188.28 \pm 63.24[88.82-360.43]$ & 36.59 & $<0.0001$ \\
\hline Sand (\%) & $34.20 \pm 9.38[13.57-49.62]$ & $46.21 \pm 13.65[18.90-75.80]$ & 23.99 & $<0.0001$ \\
\hline Maximum compaction (Mpa) & $5.83 \pm 1.19[2.94-8.61]$ & $4.43 \pm 1.86[1.45-8.30]$ & 18.76 & $<0.0001$ \\
\hline Soil depth $(\mathrm{cm})$ & $19.96 \pm 10.24[4.67-44.33]$ & $35.85 \pm 11.11[10.00-49.00]$ & 80.99 & $<0.0001$ \\
\hline
\end{tabular}

* abiotic factors were determined as followed: light availability (estimated as a Global site factor) by hemispherical photography; volumetric soil water content (VWC) with a time-domain reflectometer; $\mathrm{pH}$ with a $\mathrm{pH}$ meter; percentage of organic matter (OM) by lost of mass by combustion at $540^{\circ} \mathrm{C}$; total $\mathrm{N}$ (TN) by Kjeldahl method; C:N ratio estimated as $(\mathrm{OM} / 2) / \mathrm{TN}$; available P by the Olsen method; available $\mathrm{K}$ by inductively plasma atomic emission spectrometry; sand percentage by the Bouyoucos hydrometer method; and maximum compaction and soil depth with a penetrometer. 
when evaluated singly. We tested alternative models in which the second abiotic factor was added either additively or multiplicatively. Finally, the effect of the irrigation treatment on seedling performance was tested by comparing the general models fit to all the data (first step in the modelling process) to models that specifically distinguished between watered and control seedlings.

\section{Parameter estimation and model comparison}

We solved for the maximum likelihood parameter values using simulated annealing (Goffe et al. 1994), a global optimization procedure. The error terms $(\varepsilon)$ for the survival data were modelled using a binomial distribution, whereas the error terms for the growth data were modelled using a normal distribution. Alternate models were compared using the Akaike information criterion corrected for small sample sizes $\left(\mathrm{AIC}_{\mathrm{c}}\right.$ ) (Burnham and Anderson 2002). The absolute magnitude of the differences in $\mathrm{AIC}_{\mathrm{c}}$ between alternate models provides an objective measure of the strength of empirical support for the competing models. The model with the strongest empirical support has the lowest $\mathrm{AIC}_{\mathrm{c}}$, and thus $\Delta \mathrm{AIC}_{\mathrm{c}}=0$. Models with $\triangle \mathrm{AIC}_{\mathrm{c}}$ between 0 - are considered to have equivalent empirical support, models with $\Delta \mathrm{AIC}_{\mathrm{c}}=2-10$ are considered to have considerably less empirical support, and models with $\Delta \mathrm{AIC}_{\mathrm{c}}>10$ are considered to have essentially no empirical support (Burnham and Anderson 2002). We used asymptotic 2-unit support intervals to assess the strength of evidence for individual maximum likelihood parameter estimates (Edwards 1992). The $\mathrm{R}^{2}$ of the regression of observed vs predicted was used as a measure of goodness of fit of each alternate model. All analyses were performed using the likelihood package ver. 1.1 for $\mathrm{R}$ (available at $<$ http:// www.ecostudies.org/lme_R_code_tutorials.html $>$ ) and software written specifically for this study in $\mathrm{R}$ ver. 2.5.0.

\section{Results}

\section{Abiotic environment}

The two study sites differed in all the abiotic variables measured (Table 2). Mean and minimum GSF values were higher in Sierra Nevada than in Alcornocales. $\mathrm{VWC}_{\text {spring }}$ values in Sierra Nevada were half those of Alcornocales. $\mathrm{VWC}_{\text {spring }}$ in Alcornocales reached values up to $100 \%$, and waterlogging was observed in several microsites (unpubl.). VWC $_{\text {summer }}$ was also lower in Sierra Nevada than in Alcornocales, although the differences were less than for $\mathrm{VWC}_{\text {spring. }}$. Irrigated seedlings had higher $\mathrm{VWC}_{\text {summer }}$ than control seedlings at the two study sites $(7.66 \pm 1.78 \%$ vs $6.27 \pm 1.87 \%$ in Sierra Nevada, $9.67 \pm 2.28 \%$ vs $8.56 \pm$ $1.98 \%$ in Alcornocales; $\mathrm{p}<0.05$ in both cases, one-way ANOVAs). The somewhat limited difference between treatments is probably influenced by the fact that $\mathrm{VWC}_{\text {summer }}$ measurements were taken a few days (3-5) after water was added, therefore overlooking initial major differences. Soils in Sierra Nevada were overall moderately basic ( $\mathrm{pH}=7.89 \pm 0.29$ ), but in Alcornocales mostly acid $(\mathrm{pH}=6.19 \pm 0.57)$ though with some basic patches (i.e. $\mathrm{pH}$ values as high as 8.30). Sierra Nevada had lower OM content, total $\mathrm{N}$, and available $\mathrm{K}$ than Alcornocales, but higher P content (although P values were very low at both sites). Soils in Sierra Nevada were shallower, more compacted, and less sandy than at Alcornocales (Table 2).

We found significant correlations (both positive and negative) among several abiotic variables at the two study sites (Appendix 1). In Sierra Nevada, soils in shadier microsites were in general more acidic, sandier, deeper, wetter (in spring), and more fertile than soils in high-light microsites. In Alcornocales, soils in shadier microsites were in general drier (in spring) and richer (especially in $\mathrm{P}$ ) than in higher-light microsites.

\section{First-year seedling survival}

The magnitude of seedling survival and the identity of the main abiotic factors controlling first-year survival varied among sites, but they were relatively constant for all species within each site. First-year survival was much higher in Sierra Nevada $(80-90 \%)$ than in Alcornocales $(40-50 \%$, values corresponding to parameter a in null models, Appendix 2). Summer drought was the main cause of mortality at both sites. In Sierra Nevada, GSF was by far the best survival predictor for Q. ilex and Q. pyrenaica (Table 3). Survival decreased linearly with GSF for both species (Fig. 1a). The decrease of survival with increasing light availability was stronger for $Q$. pyrenaica as indicated by a steeper slope (i.e. larger $b$ parameter) in the linear model (Appendix 2). However, the support intervals for this parameter overlapped for the two species, indicating the lack of a strong support for a species-specific response to light. There was also evidence for effects of several soil factors on Q. pyrenaica survival (i.e. models including these factors had lower $\mathrm{AIC}_{\mathrm{c} 1}$ scores than the null model), but with considerably less empirical support than for GSF effects (Table 3). Thus, Q. pyrenaica survival was predicted to decrease linearly with $\mathrm{pH}$, and increase with the C:N ratio and sand percentage. However, this finding may be at least partially the result of the strong correlation of the three soil variables with GSF in Sierra Nevada (Appendix 1). In Alcornocales, $\mathrm{VWC}_{\text {spring }}$ was the best predictor of seedling survival for all species, survival decreasing logistically with increasing $\mathrm{VWC}_{\text {spring }}$ (Table 3, Fig. 1b). The magnitude of the decrease was stronger for $Q$. pyrenaica (larger values of the $b$ parameter, Appendix 2) than for Q. suber and $Q$. canariensis. There was also strong empirical support (i.e. $\triangle \mathrm{AIC}_{\mathrm{cl}}<2$ ) for a linear negative effect of GSF on first-year survival, but only for the two deciduous species (Q. canariensis and Q. pyrenaica). Among the two deciduous, the magnitude of the decrease was again stronger for Q. pyrenaica (Appendix 2). Bivariate models never had stronger empirical support (i.e. $\mathrm{AIC}_{\mathrm{c} 1}$ scores at least 2 units lower) than univariate models at either of the two sites.

Models differentiating among watered and control seedlings had in all cases much stronger empirical support than models that did not (i.e. $\mathrm{AIC}_{\mathrm{c} 1}-\mathrm{AIC}_{\mathrm{c} 2}>2$, Table 3). In Sierra Nevada, irrigation increased first-year survival from $\sim 75 \%$ to $\sim 90 \%$ in the two species (Appendix 2). In Alcornocales, irrigation doubled survival in Q. canariensis and Q. pyrenaica (from $\sim 35 \%$ to $\sim 70 \%$ ), but had a weaker effect in Q. suber (from $\sim 35 \%$ to $\sim 47 \%$ ). In fact, for Q. suber, support intervals for the a parameter in the 
Table 3. Summary of the models analysing the response of first-year seedling survival to abiotic factors, with all seedlings pooled in one group $\left(\mathrm{AIC}_{\mathrm{c} 1}\right)$ or separated into two (watered vs. control, $\left.\mathrm{AIC}_{\mathrm{c} 2}\right)$. For each site and species, models are ranked from best $\left(\Delta \mathrm{AIC} \mathrm{c}_{\mathrm{c} 1}=0\right)$ to poorest fits. Bold font denotes models with equivalent empirical support (within $2 \mathrm{AIC}_{\mathrm{c} 1}$ units). $\mathrm{R}^{2}$ is given for the best model. LIN, linear model; LGT, logistic model.

\begin{tabular}{|c|c|c|c|c|c|c|}
\hline Study site & Abiotic factor & Model & $\mathrm{AlC}_{\mathrm{c} 1}$ & $\Delta \mathrm{AIC}_{\mathrm{c} 1}$ & $\mathrm{R}^{2}$ & $\mathrm{AIC}_{\mathrm{c} 1}-\mathrm{AIC}_{\mathrm{c} 2}$ \\
\hline \multirow[t]{2}{*}{ Sierra Nevada } & $\begin{array}{l}\text { Quercus ilex } \\
\text { GSF } \\
\text { null }\end{array}$ & LIN & $\begin{array}{l}136.71 \\
145.70\end{array}$ & $\begin{array}{l}\mathbf{0} \\
8.99\end{array}$ & 0.11 & $\begin{array}{l}7.59 \\
7.09\end{array}$ \\
\hline & $\begin{array}{l}\text { Quercus pyrenaica } \\
\text { GSF } \\
\text { pH } \\
\mathrm{C}: \mathrm{N} \\
\text { sand } \\
\text { null }\end{array}$ & $\begin{array}{l}\text { LIN } \\
\text { LIN } \\
\text { LIN } \\
\text { LIN }\end{array}$ & $\begin{array}{l}177.05 \\
188.28 \\
190.72 \\
194.60 \\
199.49\end{array}$ & $\begin{array}{c}\mathbf{0} \\
11.23 \\
13.67 \\
17.55 \\
22.44\end{array}$ & 0.14 & $\begin{array}{l}5.44 \\
4.63 \\
8.57 \\
4.51 \\
4.80\end{array}$ \\
\hline \multirow[t]{3}{*}{ Alcornocales } & $\begin{array}{l}\text { Quercus suber } \\
\text { VWC } \\
\text { null }\end{array}$ & LGT & $\begin{array}{l}275.87 \\
278.32\end{array}$ & $\begin{array}{l}\mathbf{0} \\
2.45\end{array}$ & 0.10 & $\begin{array}{l}8.41 \\
2.03\end{array}$ \\
\hline & $\begin{array}{l}\text { Quercus canariensis } \\
\text { VWC } \\
\text { GSFring } \\
\text { null }\end{array}$ & $\begin{array}{l}\text { LGT } \\
\text { LIN }\end{array}$ & $\begin{array}{l}226.62 \\
227.70 \\
230.08\end{array}$ & $\begin{array}{l}\mathbf{0} \\
\mathbf{1 . 0 8} \\
3.46\end{array}$ & 0.10 & $\begin{array}{l}24.06 \\
21.27 \\
19.48\end{array}$ \\
\hline & $\begin{array}{l}\text { Quercus pyrenaica } \\
\text { VWC } \\
\text { GSpring } \\
\text { Null }\end{array}$ & $\begin{array}{l}\text { LGT } \\
\text { LIN }\end{array}$ & $\begin{array}{l}202.29 \\
203.19 \\
241.61\end{array}$ & $\begin{array}{c}\mathbf{0} \\
\mathbf{0 . 9 0} \\
39.32\end{array}$ & 0.24 & $\begin{array}{l}18.20 \\
17.55 \\
17.94\end{array}$ \\
\hline
\end{tabular}

Note: only abiotic factors for which models had a stronger empirical support (i.e. $\mathrm{AlC}_{\mathrm{c} 1}$ at least 2 units lower) than the null model are shown.

(a) Sierra Nevada

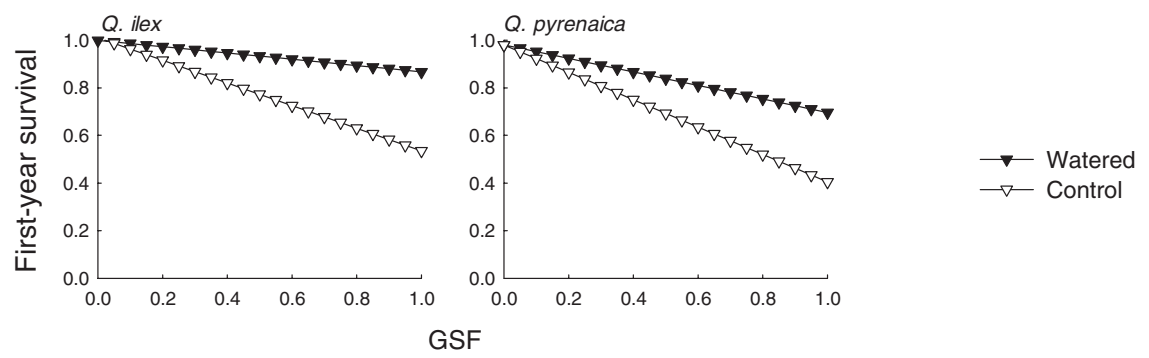

(b) Alcornocales
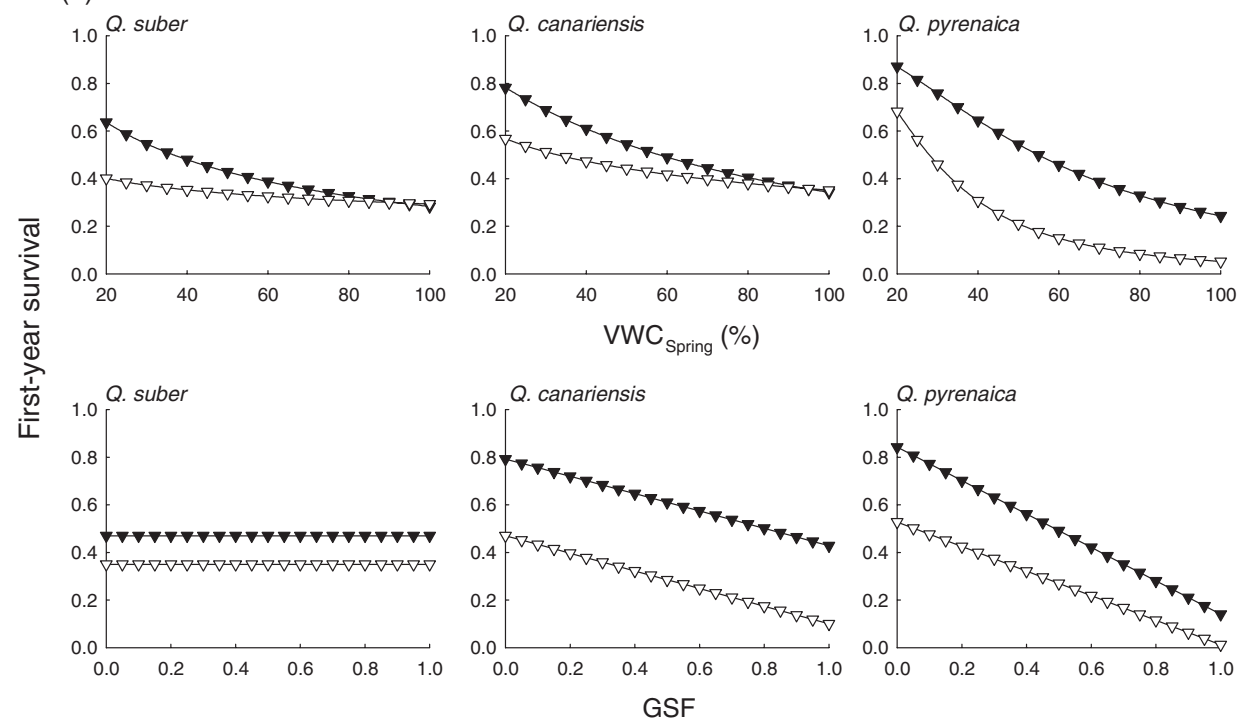

Figure 1. Predicted variation in first-year survival of watered and control seedlings as a function of the best abiotic predictors (Table 3) using the equations and parameters reported in Appendix 2. Straight lines for some combinations of species and factors denote no effect of the abiotic factor on first-year survival, and are included only for comparative purposes. 
null model (which indicates predicted mean survival) overlapped among the two treatments (Appendix 2). The positive effects of irrigation were restricted to high GSF levels in Sierra Nevada, probably because mortality at low light was almost nil even for control seedlings (Fig. 1a). On the contrary, in Alcornocales (where mortality was higher) irrigation had a positive effect throughout the entire light gradient, and boosted survival mainly at the lower end of the $\mathrm{VWC}_{\text {spring }}$ gradient (Fig. 1b).

\section{Final seedling survival}

Survival after two growing seasons was much lower than first-year survival, but differences among sites remained; final survival was much higher in Sierra Nevada than in Alcornocales. For example, survival of $Q$. pyrenaica (the only common species to the two sites) was more than twice as high in Sierra Nevada (36\%) as in Alcornocales (14\%; Appendix 3). Differences among species appeared for final survival; in Sierra Nevada Q. ilex had higher predicted survival (58\%) than Q. pyrenaica (36\%), whereas survival for Q. canariensis (28\%) was higher than for Q. pyrenaica (14\%) and Q. suber (11\%) in Alcornocales (Appendix 3).

After two growing seasons, the $\mathrm{R}^{2}$ of the best models and the number of abiotic factors having an effect on survival increased in comparison to the first year, especially in Sierra Nevada (Table 4). At this site, GSF was again the main predictor of survival for both $Q$. ilex and Q. pyrenaica (as in the first year), but this time light interacted with soil factors to determine patterns of final seedling survival (i.e. bivariate models had lower AIC scores than models including only GSF). For Q. ilex, survival increased linearly with soil P, with survival at the high end of the $\mathrm{P}$ gradient about $30 \%$ greater than survival at the low end of the gradient across all GSF conditions. For Q. pyrenaica, survival increased

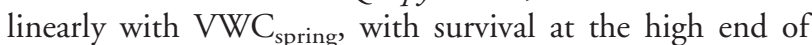
the $\mathrm{VWC}_{\text {spring }}$ gradient about $20 \%$ greater than survival at the low end of the gradient across all GSF conditions (Fig. 2a, Appendix 3). In Alcornocales, $\mathrm{VWC}_{\text {spring }}$ remained the best predictor of survival after two growing seasons, followed by GSF for the two deciduous Quercus. However, after two growing seasons some of the models including soil

Table 4. Summary of the models analysing the response of second-year seedling survival to abiotic factors, with all seedlings pooled in one group $\left(\mathrm{AIC}_{\mathrm{c} 1}\right)$ or separated into two (watered vs. control, $\left.\mathrm{AIC}_{\mathrm{c} 2}\right)$. For each site and species, models are ranked from best $\left(\Delta \mathrm{AIC} \mathrm{c}_{\mathrm{c} 1}=0\right)$ to poorest fits. Bold font denotes models with equivalent empirical support (within $2 \mathrm{AIC}_{\mathrm{c}}$ units). $\mathrm{R}^{2}$ is given for the best model. LIN, linear model; EXP, exponential model; LGT, logistic model.

\begin{tabular}{|c|c|c|c|c|c|c|}
\hline Study site & Abiotic factor & Model & $\mathrm{AIC}_{\mathrm{c} 1}$ & $\Delta \mathrm{AIC}_{\mathrm{c} 1}$ & $\mathrm{R}^{2}$ & $\mathrm{AIC}_{\mathrm{c} 1}-\mathrm{AIC}_{\mathrm{C} 2}$ \\
\hline Sierra Nevada & $\begin{array}{l}\text { Quercus ilex } \\
\text { GSF+P } \\
\text { GSF } \\
\text { pH } \\
\text { sand } \\
\text { C:N } \\
\text { soil depth } \\
\text { P } \\
\text { VWC spring } \\
\text { null } \\
\text { Quercus pyrenaica } \\
\text { GSF+VWC } \text { spring }_{\text {GSF }} \\
\text { pH } \\
\text { P+VWC } \\
\text { VWCring } \\
\text { VWCring } \\
\text { C:N } \\
\text { P+Soil depth } \\
\text { P } \\
\text { Sand } \\
\text { soil depth } \\
\text { null }\end{array}$ & $\begin{array}{l}\text { LIN } \\
\text { LIN } \\
\text { LIN } \\
\text { LIN } \\
\text { LIN } \\
\text { LIN } \\
\text { LGT } \\
\text { LIN } \\
\text { LIN } \\
\text { LGT } \\
\text { EXP }\end{array}$ & $\begin{array}{l}193.88 \\
196.39 \\
227.96 \\
238.39 \\
242.56 \\
243.88 \\
244.28 \\
247.68 \\
249.69 \\
248.45 \\
251.73 \\
260.28\end{array}$ & $\begin{array}{c}\mathbf{0} \\
2.44 \\
49.31 \\
52.99 \\
53.76 \\
59.35 \\
59.73 \\
61.48 \\
67.84 \\
\\
\\
\mathbf{0} \\
2.51 \\
34.08 \\
44.50 \\
48.70 \\
50.00 \\
50.40 \\
53.80 \\
55.81 \\
54.47 \\
57.85 \\
66.40\end{array}$ & . & $\begin{array}{r}1.01 \\
1.43 \\
-2.30 \\
0.98 \\
-3.71 \\
-4.05 \\
-5.13 \\
-0.74 \\
-0.78 \\
\\
-1.02 \\
1.99 \\
0.11 \\
1.44 \\
0.78 \\
0.98 \\
1.98 \\
-0.57 \\
1.99 \\
0.16 \\
-2.47 \\
0.90\end{array}$ \\
\hline Alcornocales & $\begin{array}{l}\text { Quercus suber } \\
\text { VWC } \\
\text { K } \\
\text { null } \\
\text { Quercus } \\
\text { VWC }_{\text {spring }} \\
\text { GSF } \\
\text { P } \\
\text { null } \\
\text { Quercus pyrenaica } \\
\text { VWC } \\
\text { GSF } \\
\text { null }\end{array}$ & $\begin{array}{l}\text { LGT } \\
\text { LIN } \\
\text { LIN }\end{array}$ & $\begin{array}{l}187.12 \\
189.23 \\
193.40 \\
195.43\end{array}$ & $\begin{array}{l}\mathbf{0} \\
2.11 \\
6.28 \\
8.31\end{array}$ & 0.09 & $\begin{array}{r}1.63 \\
-3.09 \\
-2.04 \\
\\
1.74 \\
1.45 \\
-1.80 \\
-1.23 \\
-2.34 \\
-4.23 \\
-2.07\end{array}$ \\
\hline
\end{tabular}

Note: only abiotic factors for which models had a stronger empirical support (i.e. $\mathrm{AlC}_{\mathrm{c} 1}$ at least 2 units lower) than the null model are shown. Bivariate models were included only when they had stronger empirical support than any of the univariate models analysing the two factors separately. 

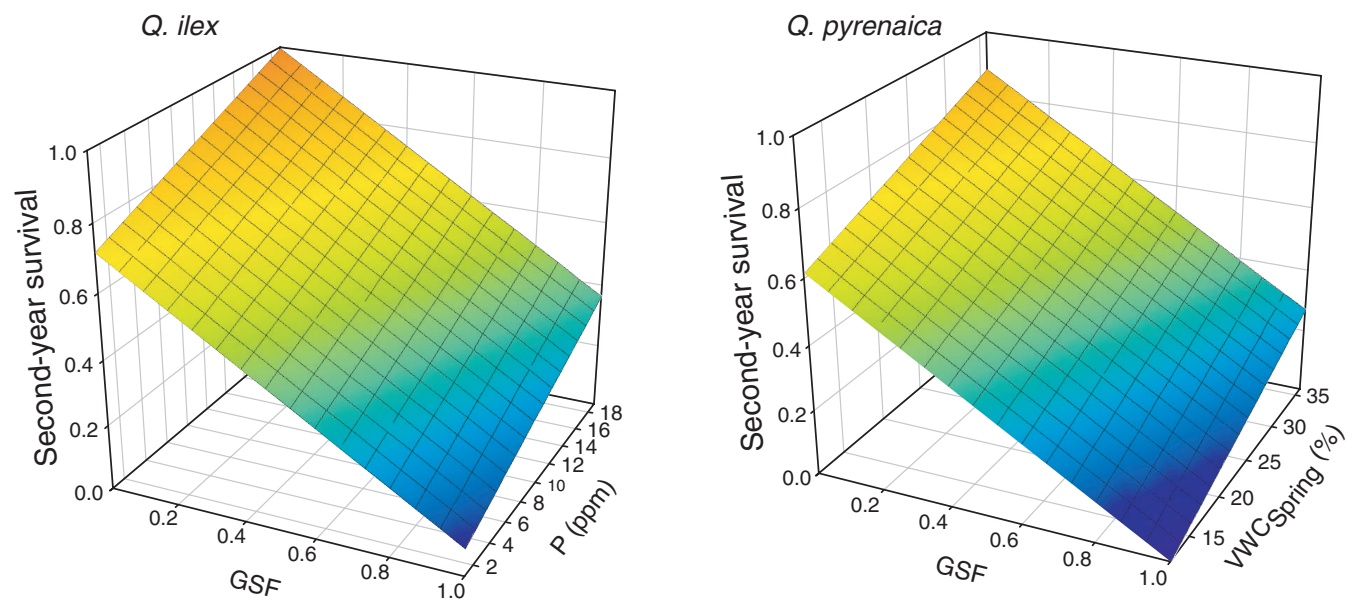

(b) Alcornocales
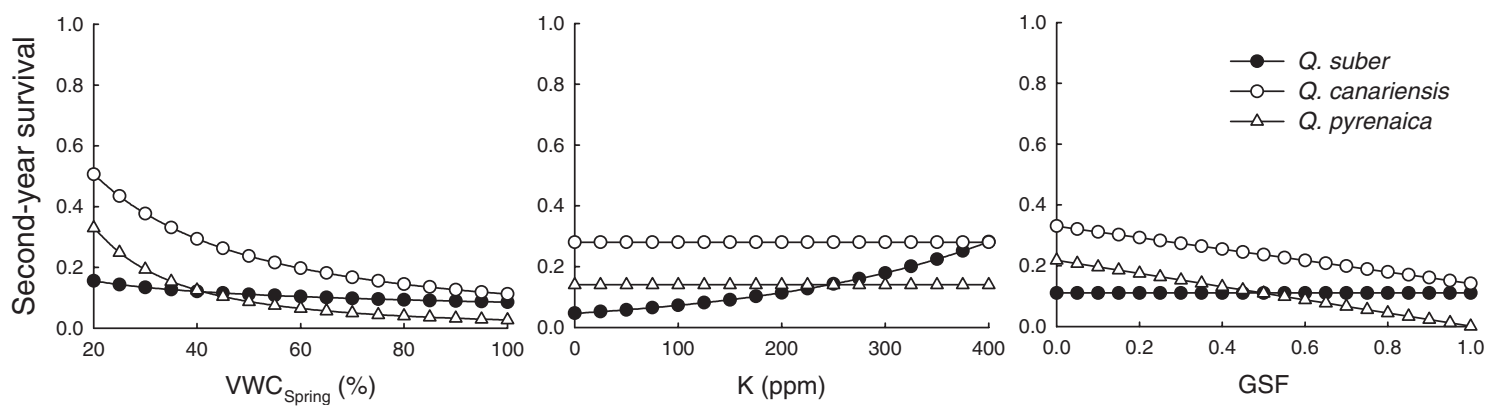

Figure 2. Predicted variation in second-year seedling survival (watered and control seedlings pooled) as a function of the best abiotic predictors for each species (Table 4) using equations and parameters reported in Appendix 3. Straight lines for some combinations of species and factors denote no effect of the abiotic factor on second-year survival, and are included only for comparative purposes.

nutrients also had stronger empirical support than the null model (Table 4). For Q. suber, survival increased exponentially with $\mathrm{K}$, whereas $Q$. canariensis survival increased linearly with P (Fig. 2b, Appendix 3).

The irrigation treatment (applied during the first year) did not augment final (i.e. after two growing seasons) seedling survival for any combination of site and species (i.e. $\mathrm{AIC}_{\mathrm{c} 1}-\mathrm{AIC}_{\mathrm{c} 2}<2$ for the 5 null models, Table 4). Moreover, it did not alter the seedling response to the best abiotic predictors of final survival (i.e. $\mathrm{AIC}_{\mathrm{c} 1}-\mathrm{AIC}_{\mathrm{c} 2}<2$ for all abiotic factors, Table 4).

\section{Seedling aboveground biomass}

Aboveground biomass after two growing seasons and its predictors varied among sites and species. In Sierra Nevada, mean aboveground biomass of Q. pyrenaica $(265.4 \mathrm{mg}$; a parameter in the null model) was lower than for Q. ilex (425.4 mg, Appendix 4). In Alcornocales, mean aboveground biomass was also predicted to be much lower for Q. pyrenaica $(378.2 \mathrm{mg}$ ) than for the other two species (552.4 mg for Q. suber and $670.4 \mathrm{mg}$ for Q. canariensis, support intervals for the a parameter in the null model overlapped for these two species, Appendix 4). Mean aboveground biomass of $Q$. pyrenaica was lower in Sierra Nevada than in Alcornocales (30\% difference, Appendix 4).
In Sierra Nevada, aboveground biomass of $Q$. ilex and Q. pyrenaica increased linearly with both GSF and soil $\mathrm{pH}$ (Table 5, Fig. 3a), which were highly correlated with each other (Appendix 1). In Alcornocales, aboveground biomass of $Q$. suber increased exponentially with GSF. There was also evidence for a positive effect of soil $\mathrm{K}$ on Q. suber growth, but with substantially less empirical support than GSF (Table 5). Aboveground biomass of Q. canariensis decreased linearly with maximum compaction (Fig. 3b). No abiotic factor was a good predictor of $Q$. pyrenaica aboveground biomass in Alcornocales (Table 5).

The irrigation treatment did not have delayed effects on aboveground biomass for any combination of site and species (i.e. $\mathrm{AIC}_{\mathrm{c} 1}-\mathrm{AIC}_{\mathrm{c} 2}<2$ for the 5 null models, Table 5). Moreover, it did not change the seedling response to the best abiotic predictors of aboveground biomass (i.e. $\mathrm{AIC}_{\mathrm{c} 1}-$ $\mathrm{AIC}_{\mathrm{c} 2}<2$ for all abiotic factors, Table 5).

\section{Discussion}

\section{Abiotic factors affecting Quercus seedling survival and growth}

Our modelling approach, based on the analyses of seedling performance over a wide and continuous range of possible resource conditions, allowed us to identify the main abiotic axes defining the regeneration niche of four Quercus species 
Table 5. Summary of the models analysing the response of aboveground seedling biomass to abiotic factors, with all seedlings pooled in one group $\left(\mathrm{AIC}_{\mathrm{c} 1}\right)$ or separated into two (watered vs. control, $\mathrm{AIC}_{\mathrm{c} 2}$ ). For each site and species, models are ranked from best $\left(\Delta \mathrm{AIC} \mathrm{C}_{\mathrm{C}}=0\right)$ to poorest fits. Bold font denotes models with equivalent empirical support (within $2 \mathrm{AIC}_{\mathrm{c}}$ units). $\mathrm{R}^{2}$ is given for the best models. LIN, Linear model; EXP, exponential model;

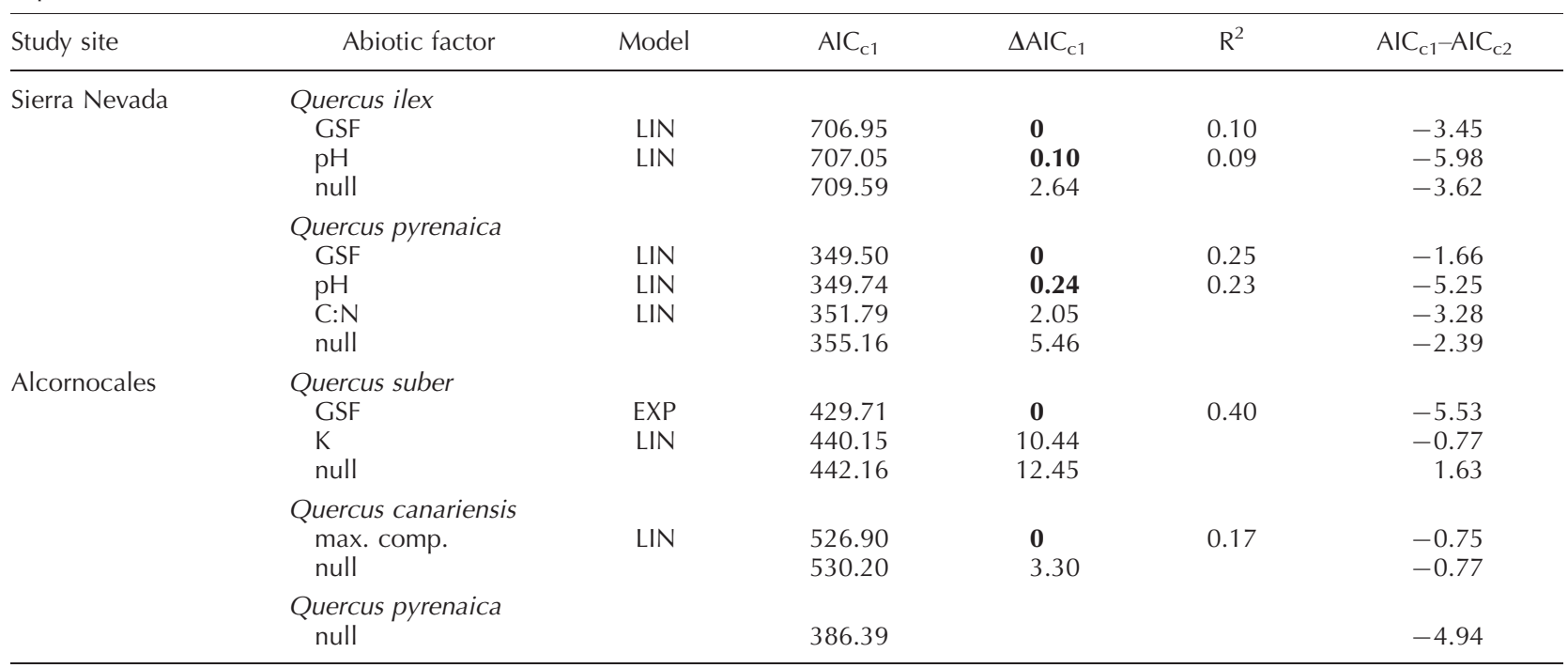

Note: only abiotic factors for which models had a stronger empirical support (i.e. $\mathrm{AlC}_{\mathrm{c} 1}$ at least two units lower) than the null model are shown.

(a) Sierra Nevada

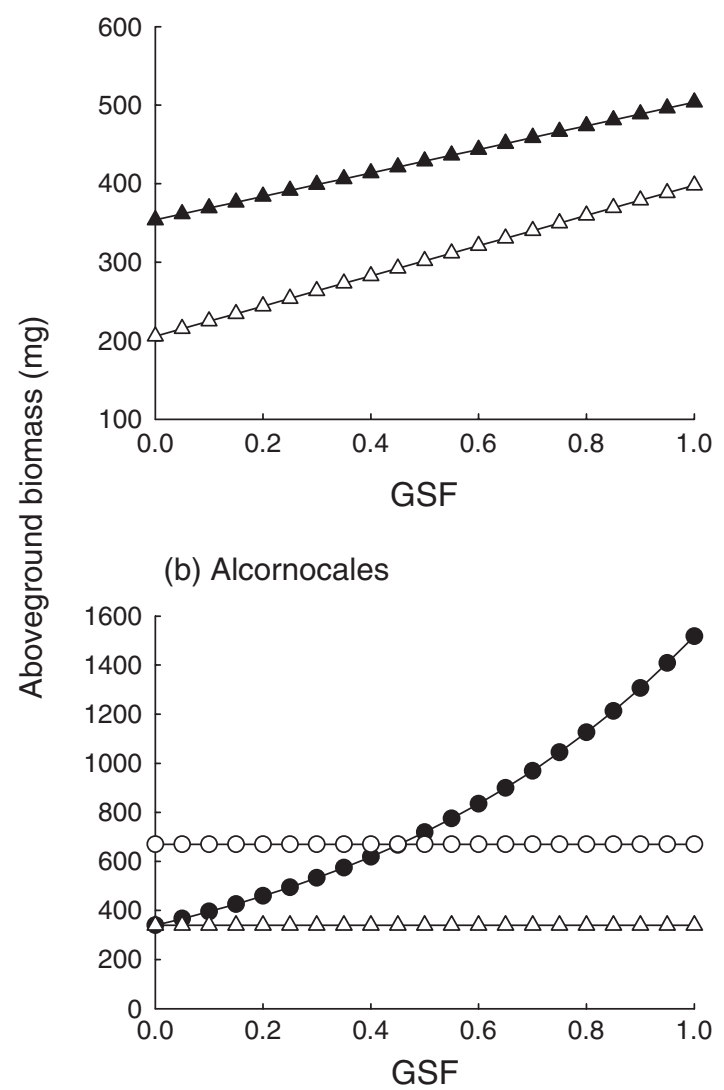

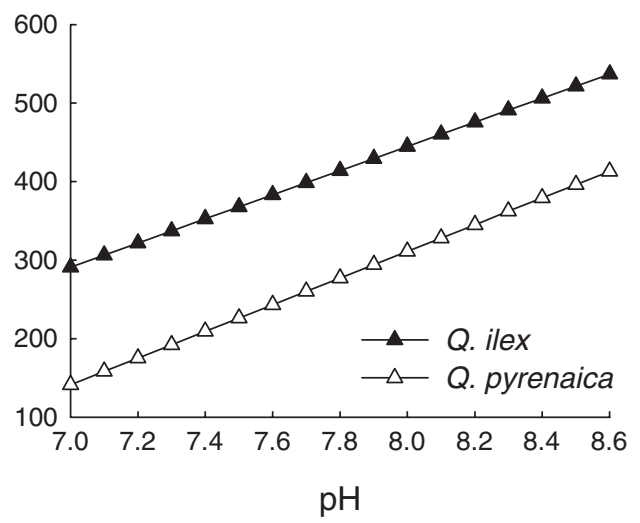

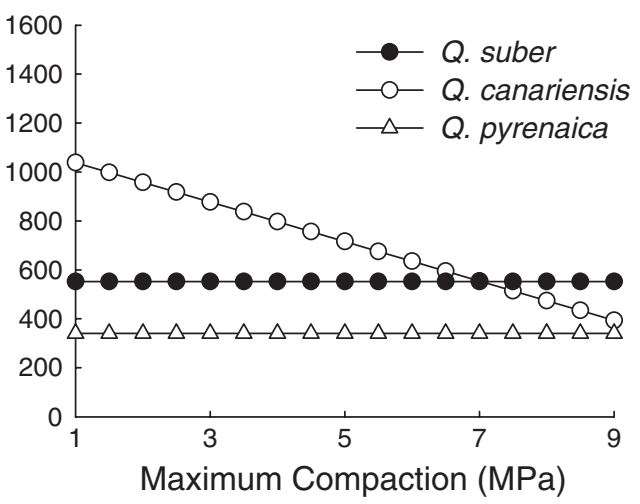

Figure 3. Predicted variation in final aboveground biomass (watered and control seedlings pooled) as a function of the best abiotic predictors (Table 5) using equations and parameters reported in Appendix 4 (note different scales between the two sites). Straight lines for some combinations of species and factors denote no effect of the abiotic factor on aboveground biomass, and are included only for comparative purposes. 
in two Mediterranean forests with contrasting abiotic characteristics. We found that these axes were largely sitedependent, with species within a site sharing in general the same best predictors and functional relationships. Light availability was by far the best predictor of seedling survival in Sierra Nevada (the drier site), supporting previous studies emphasizing light as a main environmental factor that defines the regeneration niche of Mediterranean tree species (Gómez-Aparicio et al. 2006, Puerta-Piñero et al. 2007). Seedling survival decreased linearly with light availability. The negative effects of high radiation are related to its combination with summer drought, which exacerbates the mortality risk due to a poorer plant water status, photoinhibition, and overheating (Valladares 2003). In fact, the soil water available to seedlings during the summer was notably low in most cases (Table 2), which in turn could explain why this variable was never selected in the models as a predictor of seedling survival. We detected no negative effects of shade on survival; two reasons can be adduced. First, the study species are considered shade-tolerant, at least during early life stages (Gómez-Aparicio et al. 2006, Quero et al. 2006). Second, deep shade ( $<5 \%$ full sunlight) was not part of the natural gradient of light variation at the study sites. In fact, such limiting light levels, although common in temperate and tropical forests (Canham et. al. 1990), are rarely found in Mediterranean forests (Gómez et al. 2004, Quilchano et al. 2008). We recognize that, since light was correlated with some soil characteristics (Appendix 1 ), our approach does not allow us to isolate pure light effects on performance. In fact, covariation of resources in the forest understorey is a known difficulty in explaining the role played by individual resources under natural conditions (García et al. 2006). However, the fact that univariate models including light had much stronger empirical support than any univariate model including soil factors suggests that light was the major driver of the effects in Sierra Nevada.

In Alcornocales (the wetter site), although light was also selected as one of the best predictors of survival for the two deciduous species, its relevance was somewhat confounded by its (weak) correlation with soil water content in the wet season $\left(\mathrm{VWC}_{\text {spring }}\right.$ ), the best predictor of seedling survival at this site for the three species. Survival decreased logistically with increasing $\mathrm{VWC}_{\text {spring }}$ values. Consequently, after two growing seasons, seedling survival was restricted mainly to the lower end of the $\mathrm{VWC}_{\text {spring }}$ gradient, without temporal waterlogging limitation (Fig. 2b). The negative effects of over-abundant water in spring are related to the fact that it lengthens time to emergence (Urbieta et al. pers. comm). Small delays in seedling emergence have been shown to exert negative effects on seedling fitness (Castro 2006), effects that in Mediterranean systems could come from a reduction in the time available for seedlings to develop a deep root system before the onset of the dry period. Our results therefore suggest that, at least in some Mediterranean forests with particularly high rainfall during the rainy season (like Alcornocales), water has a strong influence on regeneration not only when limiting, but also when excessive. The concurrence of a double stress by water excess (affecting emergence in spring) and deficit (desiccating seedlings in summer) could explain the much lower survival rate in Alcornocales compared to Sierra Nevada.
Moreover, this result provides a warning about the misleading use of total annual precipitation (higher in Alcornocales) as an indicator of more favorable climatic conditions for seedling establishment.

Despite light and water being the best predictors of seedling survival, soil nutrients also influenced patterns of final survival at both study sites. First-summer survival was not affected by soil nutrients, probably due to the strong dependence on acorn reserves during the first year of life (Long and Jones 1996, Quero et al. 2007; note also larger $\mathrm{R}^{2}$ for final than for first-year survival models). However, after two years, as acorn reserves become depleted and seedlings become more dependent on external sources of nutrients, seedling survival was improved by high levels of $P$ (for Q. ilex, Q. pyrenaica, and Q. canariensis) or $\mathrm{K}$ (for Q. suber). Notably, however, we found no evidence for an effect of $\mathrm{N}$ on seedling establishment, supporting previous studies showing that $\mathrm{P}$ (instead of $\mathrm{N}$ ) is the main limiting nutrient in Mediterranean forests and shrublands (Sardans et al. 2004, 2005). A mechanistic explanation for the beneficial effect of $\mathrm{P}$ and $\mathrm{K}$ on seedling performance is based on the positive effect that both nutrients have on water-use efficiency (Bradbury and Malcom 1977, Sardans et al. 2005). The positive effect of $P$ was especially evident for Q. ilex in Sierra Nevada, for which bivariate models including GSF and P had larger empirical support than models including only GSF. Thus, survival of $Q$. ilex seedlings at high $\mathrm{P}$ levels was about $30 \%$ greater than survival at low P levels across all light conditions (Fig. 2a). This light-P interaction, together with the light- $\mathrm{VWC}_{\text {spring }}$ interaction found for $Q$. pyrenaica (Fig. 2a), clearly indicates multiple resource limitation of seedling survival in Sierra Nevada. In Alcornocales, the lack of empirical support for bivariate models was probably influenced by a much lower overall seedling survival than in Sierra Nevada, which precludes detecting complex spatial patterns of survival. An alternative explanation - a spurious effect of nutrients at this site due to correlation with other main abiotic factors such as $\mathrm{VWC}_{\text {spring }}$ - seems unlikely, since no nutrient effect was detected in Alcornocales the first year despite the strong support for a water and light effect. Our results therefore suggest that, despite evident site-specific variability, multiple resource limitation shapes spatial patterns of seedling survival in Mediterranean forests.

We calibrated models of seedling survival and aboveground biomass as a function of abiotic factors, and found that the abiotic factors selected as the best predictor for survival did not always match those for biomass. Effects of a resource on seedling survival but not on growth, and vice versa, have been reported before (Kobe et al. 2002), and seem to depend on the aspect of the whole-plant physiology that the resource acts upon. For example, if soil P acted on the water-use efficiency of Quercus seedlings, it is possible that the improvement in the seedling water status would be enough to prevent summer mortality, but not to boost growth. However, we recognize that since we did not evaluate belowground biomass, we cannot preclude resource effects on root growth and root:shoot ratios. We also found that in the only case where a resource was selected as the best predictor of both survival and growth (i.e. GSF), the sign of the effect on the two performance estimators was opposite (i.e. negative for survival, positive for growth). 
Similar survival-growth conflicts have been reported before for other Mediterranean tree species and systems (Zavala et al. 2000, Marañón et al. 2004, Castro et al. 2004). Together with these studies, our results indicate that lifestage conflicts (an extension of the idea of seed-seedling conflicts proposed by Schupp 1995, 2007) mediated by light are a common phenomenon in Mediterranean forests.

\section{Do Quercus species differ in their response to resource gradients?}

Understanding differential species responses to environmental factors during establishment (i.e. in their regeneration niche) is a major issue in community ecology, largely due to their role as drivers of coexistence and dynamics in plant communities (Grubb 1977, Silvertown 2004). For differences in the regeneration niche to contribute to coexistence, species need to segregate on a resource axis and specialize by tradeoffs that prevents any species from being a superior competitor under all circumstances. Some seedling recruitment studies have found these requirements to occur (Kobe 1999, Pearson et al. 2003). However, others have not, proposing alternative mechanisms (i.e. demographic stochasticity) as potential drivers of coexistence and adult tree composition (Beckage and Clark 2003). Results from this study provide support for both lines of evidence, depending on the site considered. In Sierra Nevada, we found no evidence of regeneration niche partitioning, since $Q$. ilex outperformed Q. pyrenaica in terms of both survival and growth under all circumstances. However, despite being an inferior competitor, $Q$. pyrenaica was the only species to survive in about $10 \%$ of the sowing points, suggesting it can gain occupancy of some sites by chance (see Beckage and Clark 2003 for a similar result). According to these results, Q. ilex is the dominant oak species and Q. pyrenaica merely an accompanying species at this study site.

In Alcornocales, on the contrary, we found tradeoffs that precluded any species from outperforming the others under all resource conditions. Thus, at low light the two deciduous Quercus showed higher survival than the evergreen Q. suber, whereas $Q$. suberwas predicted to outgrow the two deciduous species in high-light microsites. This pattern is consistent with the low-light survival vs high-light growth tradeoff previously reported in other forest systems (Kobe et al. 1995, Pacala et al. 1996, Sánchez-Gómez et al. 2006). In conclusion, our results support the existence of regeneration niche partitioning at the seedling stage, but not at all sites. This implies that although differential species responses to environmental factors during establishment may help explain patterns of coexistence and tree community structure in Mediterranean forests, its relevance in comparison to other processes (i.e. demographic stochasticity) should be expected to vary markedly among communities, even when these are composed by cogeneric species.

\section{Summer rainfall, climate change and Quercus regeneration}

Our irrigation treatment evidenced the prime influence that an alteration of water availability during summer can have for regeneration in Mediterranean forests. Water addition decreased seedling mortality of all species at the two study sites, showing that summer drought is a main limitation to seedling recruitment of both evergreen and deciduous Quercus species in these forests. Under a global change scenario, summer rainfall is expected to decline in the Mediterranean region, and particularly in southern Spain (Moreno 2005, Christensen et al. 2007). Drier summers due to climate change could thus be expected to have a general negative effect on the recruitment ability of Quercus species, most of which already suffer serious regeneration problems (Gómez et al. 2003, Pérez-Ramos 2007).

Although water addition during the first summer of the experiment had immediate and positive effects on first-year survival, it did not have any delayed effect on seedling performance in the following year. At the end of the experiment neither survival nor aboveground biomass differed among watered and control seedlings. The lack of positive delayed effects on performance is presumably influenced by the fact that the second year of the experiment (2005) was extremely dry. Thus, most seedlings that had survived the first year in sub-optimal microsites (i.e. high-light microsites) ultimately died during the second drier summer. The fact that extremely dry summers can cancel out the positive effects of previous 'wet' years (as simulated with the irrigation treatment) also has important implications for predicting regeneration under future climatic conditions. Regeneration dynamics of Mediterranean tree species are highly dependent on the recruitment peaks that take place in sporadic 'wet' years (Traveset et al. 2003, Gómez-Aparicio et al. 2005), and could be expected to be even more dependent on such years in the future. Therefore, if climate change causes not only a general rainfall decrease but also a higher frequency of extreme summer droughts, it could have a double negative impact on the regeneration ability of woody species: a general reduction in the magnitude of seedling survival and the annulment of the positive effects on recruitment of the (infrequent) 'wet' years.

The relevance of summer drought as a major cause of seedling mortality in Mediterranean forests is reinforced by the fact that water addition reduced first-year mortality over the entire light gradient, indicating water deficits at all light levels (Fig. 1). The fact that even in the irrigation treatment seedling survival was much higher in the shade than in highlight is important from the standpoint of the debate on the interaction of drought and shade in Mediterranean forests (Sack and Grubb 2002, Quero et al. 2006). Specifically, it suggests that shade alleviates (and does not intensify) drought effects, even when natural drought levels are reduced through water addition. Consequently, the intensification of summer drought with climate change could be expected to be accompanied by an increase in the positive effects of shade, and therefore, with spatial patterns of regeneration restricted to shaded microsites under the canopy of trees and shrubs. In other words, we could expect an intensification of the positive nurse-plant interactions that drive regeneration dynamics in Mediterranean forests and shrublands (Gómez-Aparicio et al. 2004, Zamora et al. 2004). 


\section{Concluding remarks}

Our modelling approach has enabled us to identify seedling functional responses across resource gradients in two Mediterranean forests covering a wide range of climatic and soil conditions. We found that survival and aboveground biomass of oak seedlings varied in linear and nonlinear ways along light and soil gradients, although interestingly, the best abiotic predictors did not always match for both performance estimators. Moreover, both site-specific and general patterns emerged. Strong sitespecificity was found in the identity of the main limiting resources for seedling survival, as well as in the strength of empirical support for multiple resource limitation (higher in Sierra Nevada, the drier site) and regeneration niche partitioning (higher in Alcornocales, the wetter site). However, at both sites Quercus species shared the same response to water addition: positive immediate (first year) effects but nil delayed (after two years) effects, suggesting a species convergence in the functional response to summer drought alteration.

The results of this study, focused on resource-conservative Mediterranean oak species, must be considered a conservative assessment of the role that abiotic factors play in determining spatial patterns of seedling recruitment under current and future environmental scenarios. For example, since slow-growing oaks have a moderate nutrient demand (Cornelissen et al. 1996, Sack et al. 2003), the positive effects of nutrients on regeneration could be expected to be much greater in systems dominated by fast-growing nutrient-demanding species. Similarly, the effects of altered rainfall patterns can be expected to be even larger for more drought-sensitive species inhabiting Mediterranean forests such as those from temperate and boreal origin (Castro et al. 2004, Mendoza et al. unpubl.). In any case, even our conservative results indicate that successful early recruitment of late-successional Quercus species is very much restricted to low-light, low-waterlogging, and relatively nutrient-richer microsites, generally associated with the presence of trees and shrubs which act as nurse plants. Successful recruitment could be even more limited under a global change scenario, although many uncertainties remain. For example, although without a doubt an intensification of summer drought would negatively affect seedling survival, our results also suggest that such negative effects could be somewhat offset by parallel decreases in spring rainfall or increases in nutrient availability due to atmospheric deposition and changes in land use (Peñuelas and Filella 2001). Overall, this study constitutes a first and necessary step towards the development of a mechanistic model of Mediterranean forest dynamics that incorporates the idiosyncrasies and generalities of tree regeneration in these systems, and that allow simulation and prediction of the ecological consequences of resource level alterations due to global change.

Acknowledgements - We thank the Consejería de Medio Ambiente (Andalusian Government) and the directors of the Sierra Nevada National Park and Alcornocales Natural Park for facilities and support to carry out the field work. We also thank Rafael Villar for his advice in the experimental design of seedling growth measure- ments and for providing Q. pyrenaica acorns; and Luis V. García, Eduardo Gutiérrez, Ana Polo, Rocío Sánchez, Maite Domínguez, Carmen Navarro, Sergio de Haro, Asier Herrero, Ángel Navarro and Joaquín Sánchez for invaluable lab and field assistance. Many thanks to Lora Murphy and Charlie Canham for developing and providing the likelihood package for statistical analyses. Eugene W. Schupp provided helpful comments on an earlier version of the manuscript. This study was supported by a Juan de la Cierva contract to L.G.A, grants FPU-MEC to I.M.P.R. and I.M., grants FPI-MEC to J.L.Q. and L.M. and by the coordinated Spanish MEC projects HETEROMED (REN2002-04041-C02) and DINAMED (CGL2005-05830-C03). This research is part of REDBOME ( < www.ugr.es/ redbome/ $>$ ) and GLOBIMED $(<$ www.globimed.net $>$ ) networks on forest ecology.

\section{References}

Anonymous 1994. Métodos oficiales de análisis. Vol. III. - Ministerio de Agricultura, Pesca y Alimentación.

Beckage, B. and Clark, J. S. 2003. Seedling survival and growth of three forest tree species: the role of spatial heterogeneity. - Ecology 84: 1849-1861.

Blanco, E. et al. 2005. Los bosques ibéricos. Una interpretación geobotánica. - Editorial Planeta.

Bradbury, I. K. and Malcom, D. C. 1977. The effect of phosphorus and potassium on transpiration, leaf diffusive resistance and water-use efficiency in Sitka spruce (Picea sitchensis) seedlings. - J. Appl. Ecol. 14: 631-641.

Burnham, K. P. and Anderson, D. R. 2002. Model selection and multimodel inference: a practical information-theoretic approach (2nd ed.). - Springer.

Canadell, J. G. et al. (eds) 2006. Terrestrial ecosystems in a changing world. - Springer.

Canham, C. D. et al. 1990. Light regimes beneath close canopies and tree-fall gaps in temperate and tropical forests. - Can. J. For. Res. 20: 620-631.

Castro, J. 2006. Short delay in timing of emergence determines establishment success in Pinus sylvestris across microhabitats. - Ann. Bot. 98: 1233-1240.

Castro, J. et al. 2004. Seedling establishment of a boreal tree species (Pinus sylvestris) at its southernmost distribution limit, consequences of being in a marginal Mediterranean area. - J. Ecol. 92: 266-277.

Chapin III, F. S. et al. (eds) 2001. Global biodiversity in a changing environment. - Springer.

Christensen, J. H. et al. 2007. Regional climate projections. Contribution of working group I to the fourth assessment report of the IPCC. - In: Solomon, S. et al. (eds), Climate change 2007: The physical science basis. Cambridge Univ. Press, pp. 847-943.

Coomes, D. A. and Grubb, P. J. 2000. Impacts of root competition in forests and woodlands: a theoretical framework and review of experiments. - Ecol. Monogr. 70: 171-207.

Cornelissen, J. H. C. et al. 1996. Seedling growth, allocation and leaf attributes in a wide range of woody plant species and types. - J. Ecol 84: 755-765.

Edwards, A. W. F. 1992. Likelihood. Expanded edition. - Johns Hopkins Univ. Press.

Espelta, J. M. et al. 2005. Differences in biomass partitioning, leaf nitrogen content, and water use efficiency (delta C-13) result in similar performance of seedlings of two Mediterranean oaks with contrasting leaf habit. - Ecoscience 12: 447-454.

García, L. V. 2004. Escaping the Bonferroni iron claw in ecological studies. - Oikos 105: 657-663. 
García, L. V. et al. 2006. Counteracting gradients of light and soil nutrients in the understorey of Mediterranean oak forests. - Web Ecol. 6: 67-74.

Goffe, W. L. et al. 1994. Global optimization of statistical functions with simulated annealing. - J. Econometrics 60: 6599.

Gómez, J. M. 2004. Importance of burial and microhabitat on Quercus ilex early recruitment: non-additive effects on multiple demographic processes. - Plant Ecol. 172: 287-297.

Gómez, J. M. et al. 2003. Impact of vertebrate acorn- and seedling-predators on a Mediterranean Quercus pyrenaica forest. - For. Ecol. Manage. 180: 125-134.

Gómez, J. M. et al. 2004. Differences between structural and functional environmental heterogeneity caused by seed dispersal. - Funct. Ecol. 18: 787-792.

Gómez-Aparicio, L. et al. 2004. Applying plant facilitation to forest restoration in Mediterranean ecosystems: a meta-analysis of the use of shrubs as nurse plants. - Ecol. Appl. 14: 11281138.

Gómez-Aparicio, L. et al. 2005. Microhabitats shift rank in suitability for seedling establishment depending on habitat type and climate. - J. Ecol. 93: 1194-1202.

Gómez-Aparicio, L. et al. 2006. Differential light responses of Mediterranean tree saplings: linking ecophysiology with regeneration niche in four co-occurring species. - Tree Physiol. 26: 947-958.

Grubb, P. J. 1977. The maintenance of species richness in plant communities: the importance of the regeneration niche. - Biol. Rev. 52: 107-145.

Harper, J. L. 1977. Population biology of plants. - Academic Press.

Herrera, C. M. et al. 1994. Recruitment of a mast-fruiting birddispersed tree: bridging frugivore activity and seedling establishment. - Ecol. Monogr. 64: 315-344.

Ibañez, I. and Schupp, E.W. 2001. Positive and negative interactions between environmental conditions affecting Cercocarpus ledifolius seedling survival. - Oecologia 129: 543-550.

Kitajima, K. and Fenner, M. 2000. Ecology of seedling regeneration. - In: Fenner, M. (ed), Seeds: the ecology of regeneration in plant communities. CAB Int., pp. 331-359.

Kobe, R. K. 1999. Light gradient partitioning among tropical tree species through differential seedling mortality and growth. - Ecology 80: 187-201.

Kobe, R. K. et al. 1995. Juvenile tree survivorship as a component of shade tolerance. - Ecol. Appl. 5: 517-532.

Kobe, R. K. et al. 2002. Tree seedling growth and mortality responses to manipulations of calcium and aluminum in a northern hardwood forest. - Can. J. For. Res. 32: 954-966.

Long, T. J. and Jones, R. H. 1996. Seedling growth strategies and seed size effects in fourteen oak species native to different soil moisture habitats. - Trees 11: 1-8.

Marañón, T. et al. 2004. Regeneration of tree species and restoration under contrasted Mediterranean habitats: field and glasshouse experiments. - Int. J. Ecol. Environ. Sci. 30: 187-196.

Moreno, J. M. (ed.) 2005. Principales conclusiones de la evaluación preliminar de los impactos en España por efecto del cambio climático. - Ministerio de Medio Ambiente.

Nelson, D. W. and Sommers, L. E. 1982. Total carbon, organic carbon, and organic matter. - In: Page, A.L. et al. (eds), Methods of soil analysis (2nd ed.). Am. Soc. Agro., Soil Sci. Soc. Am., pp. 539-579.

Pacala, S. W. et al. 1994. Sapling growth as a function of resources in a north temperate forest. - Can. J. For. Res. 24: 21722183.

Pacala, S. W. et al. 1996. Forest models defined by field measurements: estimation, error analysis, and dynamics. - Ecol. Monogr. 66: 1-43.
Pearson, T. R. H. et al. 2003. Regeneration niche partitioning in neotropical pioneers: effects of gap size, seasonal drought and herbivory on growth and survival. - Oecologia 137: 456-465.

Peñuelas, J. and Filella, I. 2001. Herbaria century record of increasing eutrophication in Spanish terrestrial ecosystems. - Global Change Biol. 7: 427-433.

Peñuelas, J. et al. 2004. Efectos del cambio climático sobre los ecosistemas terrestres: observación, experimentación y simulación. - In: Valladares, F. (ed.), Ecología del Bosque Mediterráneo en un Mundo Cambiante. Naturaleza y Parques Nacionales. Ministerio de Medio Ambiente, pp. 425-460.

Pérez-Ramos, I. M. 2007. Factores que condicionan la regeneración natural de especies leñosas en un bosque mediterráneo del sur de la Península Ibérica. PhD thesis. - Univ. de Sevilla.

Puerta-Piñero, C. et al. 2007. Irradiance and oak seedling survival and growth in a heterogeneous environment. - For. Ecol. Manage. 242: 462-469.

Quero, J. L. et al. 2006. Interactions of drought and shade effects on seedlings of four Quercus species: physiological and structural leaf responses. - New Phytol. 170: 819-834.

Quero, J. L. et al. 2007. Seed mass effects in four Mediterranean Quercus species growing in contrasting light environments. - Am. J. Bot. 94: 1795-1803.

Quilchano, C. et al. 2008. Patterns and ecological consequences of abiotic heterogeneity in managed cork-oak forests of Southern Spain. - Ecol. Res. 23: 127-139

Rich, P. M. 1990. Characterizing plant canopies with hemispherical photographs. - Remote Sens. Rev. 5: 13-29.

Sack, L. and Grubb, P. J. 2002. The combined impacts of deep shade and drought on the growth and biomass allocation of shade-tolerant woody seedlings. - Oecologia 131: 175-185.

Sack, L. et al. 2003. The functional morphology of plant juveniles tolerant of deep shade plus drought in three Mediterraneanclimate forests of southern Spain. - Plant Ecol. 168: 139-163.

Sánchez-Gómez, D. et al. 2006. Performance of seedlings of Mediterranean woody species under experimental gradients of irradiance and water availability: tradeoffs and evidence for niche differentiation. - New Phytol. 170: 795-806.

Sardans, J. et al. 2004. Phosphorus limitation and competitive capacities of Pinus halepensis and Quercus ilex subsp. rotundifolia on different soils. - Plant Ecol. 174: 305-317.

Sardans, J. et al. 2005. Changes in nutrient use efficiency, status and retranslocation in young post-fire regeneration Pinus halepensis in response to sudden $\mathrm{N}$ and $\mathrm{P}$ input, irrigation and removal of competing vegetation. - Trees 19: 233-250.

Schröter, D. et al. 2005. Ecosystem service supply and vulnerability to global change in Europe. - Science 310: 1333-1337.

Schupp, E. W. 1995. Seed-seedling conflicts, habitat choice, and patterns of plan recruitment. - Am. J. Bot. 82: 399-409.

Schupp, E. W. 2007. Suitable sites for dispersal are context dependent. - In: Dennis, A.J. et al. (eds), Seed dispersal: theory and its application in a changing world. CAB Int., pp. 445-462.

Silvertown, J. 2004. Plant coexistence and the niche. - Trends Ecol. Evol. 19: 605-611.

Traveset, A. et al. 2003. Transition probabilities from pollination to establishment in a rare dioecious shrub species (Rhamnus ludovici-salvatoris) in two habitats. - J. Ecol. 91: 427-437.

Urbieta, I. R. et al. Human and non-human determinants of forest composition in southern Spain: evidence of shifts toward cork oak dominance as a result of management over the past century. - J. Biogeogr. in press. (doi: 10.1111/j.13652699.2008.01914.x)

Valladares, F. 2003. Light heterogeneity and plants: from ecophysiology to species coexistence and biodiversity. - Progr. Bot. 64: 439-471.

Vitousek, P. M. 1994. Beyond global warming: ecology and global change. - Ecology 75: 1861-1876. 
Witkowski, E. T. F. et al. 1990. Response of Cape fynbos ecosystem to nutrient additions: shoot growth and nutrient contents of a proteoid (Leucospermun parile) and an ericoid (Phylica cephalantha) evergreen shrub. - Acta Oecol. 11: 311326.

Zamora, R. et al. 2004. Las interacciones planta-planta y plantaanimal en el contexto de la sucesión ecológica. - In: Valladares,
F. (ed.), Ecología del bosque mediterráneo en un mundo cambiante. Naturaleza y Parques Nacionales. Ministerio de Medio Ambiente, pp. 371-393.

Zavala, M. A. et al. 2000. Constraints and trade-offs in Mediterranean plant communities: the case of holm oakaleppo pine forests. - Bot. Rev. 66: 120-149.

\section{Appendix}

Appendix 1. Pearson's correlation coefficients for abiotic factors at the two study sites. ${ }^{* * * *} p<0.0001,{ }^{* * *} p<0.001,{ }^{* *} p<0.01,{ }^{*} p<0.05$. Those values that remained significant after controlling the false discovery rate are in bold.

\begin{tabular}{|c|c|c|c|c|c|c|c|c|c|c|c|}
\hline & $\begin{array}{c}\text { Soil } \\
\text { depth }\end{array}$ & $\begin{array}{l}\text { Max. } \\
\text { comp. }\end{array}$ & Sand & K & $P$ & $\mathrm{C}: \mathrm{N}$ & $\mathrm{TN}$ & OM & $\mathrm{pH}$ & $\mathrm{VWC}_{\text {Summer }}$ & $\mathrm{VWC}_{\text {Spring }}$ \\
\hline \multicolumn{12}{|l|}{ Sierra Nevada } \\
\hline GSF & $-0.50^{* * * *}$ & $-0.23 *$ & $-0.38^{* * *}$ & -0.08 & -0.14 & $-0.64^{* * * *}$ & 0.04 & $-0.23 *$ & $0.53^{* * * *}$ & * -0.12 & $-0.35^{*}$ \\
\hline $\mathrm{VWC}_{\text {spring }}$ & $0.35^{*}$ & $0.47^{* * * *}$ & 0.21 & -0.13 & $0.31^{*}$ & $0.35^{*}$ & -0.27 & 0.03 & $-0.47^{* * * *}$ & $0.30^{*}$ & \\
\hline$V W C_{\text {summer }}$ & 0.06 & 0.12 & 0.20 & -0.23 & 0.03 & -0.05 & $-0.32^{*}$ & -0.25 & -0.02 & & \\
\hline $\mathrm{PH}$ & $-0.51^{* * * *}$ & $-0.38 * * *$ & 0.01 & -0.16 & $-0.62^{* * * *}$ & $*-0.71^{* * * *}$ & $-0.36^{* *}$ & $-0.65^{* * * *}$ & & & \\
\hline OM & $0.33^{* *}$ & $0.23^{*}$ & $-0.36^{* *}$ & $0.54 * * * *$ & $0.50^{* * *}$ & $0.69^{* * * *}$ & $\quad 0.84 * * * *$ & & & & \\
\hline $\mathrm{TN}$ & 0.12 & -0.10 & $-0.57 * * * *$ & $0.66^{* * * *}$ & $0.48^{* * * *}$ & ${ }^{*}-0.22^{*}$ & & & & & \\
\hline $\mathrm{C}: \mathrm{N}$ & $0.48^{* * * *}$ & $0.38^{* * *}$ & 0.09 & $0.23^{*}$ & $0.22 *$ & & & & & & \\
\hline $\mathrm{P}$ & 0.10 & 0.17 & -0.17 & $0.25^{*}$ & & & & & & & \\
\hline K & 0.11 & -0.13 & $-0.64^{* * * *}$ & & & & & & & & \\
\hline sand & 0.14 & 0.25 & & & & & & & & & \\
\hline max. comp. & $0.56^{* * * *}$ & & & & & & & & & & \\
\hline \multicolumn{12}{|l|}{ Alcornocales } \\
\hline GSF & 0.01 & $-0.31^{*}$ & -0.20 & -0.03 & $-0.44^{* * *}$ & 0.06 & $-0.30 *$ & $-0.27^{*}$ & -0.11 & 0.14 & $0.32 *$ \\
\hline $\mathrm{VWC}_{\text {spring }}$ & 0.01 & -0.20 & -0.22 & 0.03 & $-0.28^{*}$ & 0.07 & 0.07 & 0.13 & $0.59 * * * *$ & $0.40^{* *}$ & \\
\hline VWC summer & 0.09 & 0.20 & $-0.64^{* * * *}$ & $0.34^{*}$ & -0.12 & -0.02 & $0.40^{* *}$ & $0.50 * * * *$ & * $0.50^{* * * *}$ & & \\
\hline $\mathrm{pH}$ & -0.02 & -0.11 & $-0.50^{* * * *}$ & 0.19 & $-0.29 *$ & 0.09 & 0.24 & $0.27^{*}$ & & & \\
\hline OM & 0.03 & 0.20 & $-0.64^{* * * *}$ & $0.64 * * * *$ & $0.27^{*}$ & 0.09 & $0.92 * * * *$ & & & & \\
\hline $\mathrm{TN}$ & 0.02 & 0.18 & $-0.57 * * * *$ & $0.59 * * * *$ & $0.29 *$ & $0.32 *$ & & & & & \\
\hline $\mathrm{C}: \mathrm{N}$ & 0.01 & 0.06 & -0.09 & 0.07 & 0.01 & & & & & & \\
\hline $\mathrm{P}$ & -0.22 & $0.36 * *$ & 0.15 & 0.08 & & & & & & & \\
\hline K & 0.12 & -0.03 & $-0.62^{* * * *}$ & & & & & & & & \\
\hline sand & -0.23 & 0.02 & & & & & & & & & \\
\hline max. comp. & 0.13 & & & & & & & & & & \\
\hline
\end{tabular}

Pearson's correlation coefficients for abiotic factors at the two study sites. ${ }^{* * * *} p<0.0001,{ }^{* * *} p<0.001,{ }^{* *} p<0.01,{ }^{*} p<0.05$. Those values that remained significant after controlling the false discovery rate are in bold. 


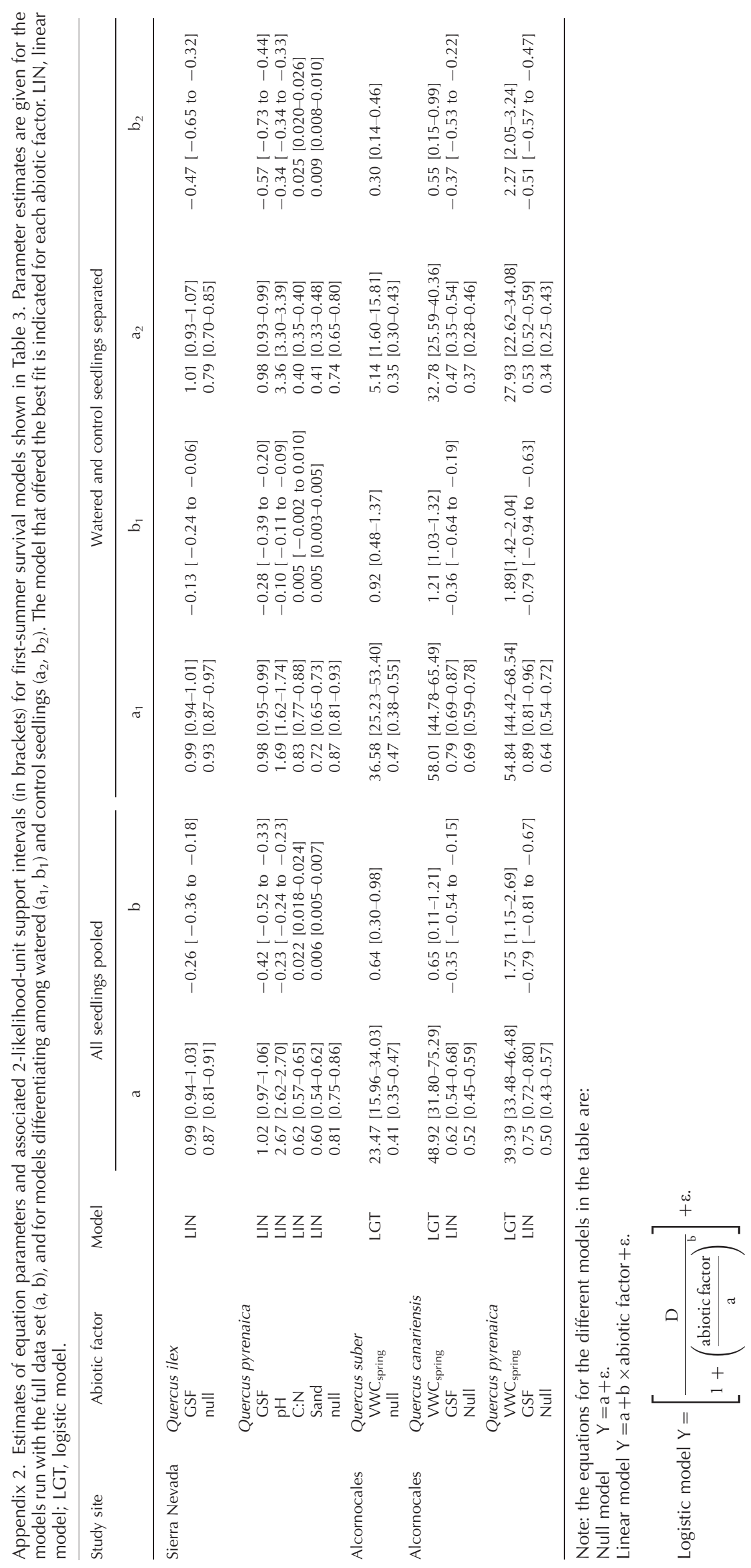


Appendix 3. Estimates of equation parameters (a, b, c) and associated 2-likelihood-unit support intervals (in brackets) for final survival models (all seedlings pooled) shown in Table 4. Parameters for the models separating among watered and control seedlings are not shown because they were never a better fit. The $c$ parameter is given only for bivariate models, and evaluates the change in survival as a function of the second abiotic factor. The model that offered the best fit is indicated for each abiotic factor. LIN, linear model; EXP, exponential model; LGT, logistic model.

\begin{tabular}{|c|c|c|c|c|c|}
\hline Site & Abiotic factor & Model & $a$ & $b$ & C \\
\hline Sierra Nevada & $\begin{array}{l}\text { Quercus ilex } \\
\text { GSF +P } \\
\text { GSF } \\
\text { pH } \\
\text { sand } \\
\text { C:N } \\
\text { soil depth } \\
\text { P } \\
\text { VWC } \\
\text { null } \\
\text { Quercus pyrenaica } \\
\text { GSF+VWC } \\
\text { GSF } \\
\text { PH } \\
\text { P+VWhing } \\
\text { VWC } C_{\text {spring }} \\
\text { VWC } \\
\text { C:N } \\
\text { P+soil depther } \\
\text { P } \\
\text { Sand } \\
\text { Soil depth } \\
\text { null }\end{array}$ & $\begin{array}{l}\text { LIN } \\
\text { LIN } \\
\text { LIN } \\
\text { LIN } \\
\text { LIN } \\
\text { LIN } \\
\text { LGT } \\
\text { LIN } \\
\text { LIN } \\
\text { LGT } \\
\text { EXP }\end{array}$ & $\begin{array}{l}0.43[0.42-0.45] \\
0.91[0.87-0.98] \\
4.92[0.87-5.02] \\
0.72[0.69-0.77] \\
-0.15[-0.20 \text { to }-0.09] \\
-0.01[-0.07 \text { to } 0.02] \\
9.10[8.19-10.10] \\
0.07[0.02-0.13] \\
0.18[0.10-0.27] \\
46.08[38.71-54.83] \\
0.18[0.15-0.21] \\
0.36[0.29-0.41]\end{array}$ & $\begin{array}{l}-0.55[-0.56 \text { to }-0.53] \\
-0.96[-0.99 \text { to }-0.86] \\
-0.58[-0.59 \text { to }-0.57] \\
-0.76[-0.80 \text { to }-0.69] \\
0.02[0.02-0.03] \\
0.04[0.03-0.05] \\
-3.83[-5.66 \text { to }-2.18] \\
0.03[0.02-0.04] \\
0.05[0.03-0.06] \\
-1.61[-2.24 \text { to }-1.03] \\
0.029[0.023-0.033]\end{array}$ & $\begin{array}{l}0.01[0.01-0.01] \\
0.003[0.001-0.014]\end{array}$ \\
\hline Alcornocales & $\begin{array}{l}\text { Quercus suber } \\
\text { VWC }_{\text {spring }} \\
\text { K } \\
\text { null } \\
\text { Quercus canariensis } \\
\text { VWC }_{\text {spring }} \\
\text { GSF } \\
\text { P } \\
\text { null } \\
\text { Quercus pyrenaica } \\
\text { VWC } \\
\text { GSFring } \\
\text { null }\end{array}$ & $\begin{array}{l}\text { LGT } \\
\text { LIN } \\
\text { LIN }\end{array}$ & $\begin{array}{l}20.38[15.89-25.88] \\
0.33[0.28-0.39] \\
0.21[0.15-0.27] \\
0.28[0.22-0.34]\end{array}$ & $\begin{array}{l}1.30[0.91-1.73] \\
-0.19[-0.28 \text { to }-0.10] \\
0.03[0.01-0.05]\end{array}$ & \\
\hline
\end{tabular}

Note: the equations for the different models in the table are:

Null model $\mathrm{Y}=\mathrm{a}+\varepsilon$

Linear model $\mathrm{Y}=\mathrm{a}+\mathrm{b} \times$ abiotic factor $+\varepsilon$

Exponential model $\mathrm{Y}=\mathrm{a} \times \exp ^{(\mathrm{b} \times \text { abiotic factor })}+\varepsilon$.

Logistic model $Y=\left[\frac{\mathrm{D}}{1+\left(\frac{\text { abiotic factor }}{\mathrm{a}}\right)}\right]+\varepsilon$.

Bivariate linear model $\mathrm{Y}=\mathrm{a}+\mathrm{b} \times$ abiotic factor $1+\mathrm{c} \times$ abiotic factor $2+\varepsilon$. 
Appendix 4. Estimates of equation parameters $(\mathrm{a}, \mathrm{b})$, variance $(\sigma)$, and associated 2-likelihood-unit support intervals (in brackets) for aboveground biomass models (all seedlings pooled) shown in Table 5. Parameters for the models separating among watered and control seedlings are not shown because they were never a better fit. The model that offered the best fit is indicated for each abiotic factor. LIN, linear model; EXP, exponential model.

\begin{tabular}{|c|c|c|c|c|c|}
\hline Study site & Abiotic factor & Model & a & $b$ & $\sigma$ \\
\hline \multirow{9}{*}{$\begin{array}{l}\text { Sierra } \\
\quad \text { Nevada }\end{array}$} & Quercus ilex & & & & \\
\hline & GSF & LIN & 353.78 [311.32-396.23] & $149.81[64.35-32.81]$ & 148.15 [123.12-183.70] \\
\hline & $\mathrm{pH}$ & LIN & $-785.94[-1865.56$ to 378.60$]$ & $153.83[16.94-290.72]$ & $158.88[128.90-188.86]$ \\
\hline & null & & $425.39[378.60-473.90]$ & & 166.04 [137.97-204.38] \\
\hline & Quercus pyrenaica & & & & \\
\hline & GSF & LIN & 205.66 [168.64-242.68] & 192.28 [93.06-294.98] & 96.44 [75.42-129.33] \\
\hline & $\mathrm{pH}$ & LIN & -1048.30 [ -1082.18 to -1015.79$]$ & ] 169.93 [164.83-175.02] & 89.35 [69.90-119.36] \\
\hline & $\mathrm{C}: \mathrm{N}$ & LIN & $471.98[324.56-619.40]$ & $-22.98[-38.98$ to -6.97$]$ & $90.60[67.44-113.75]$ \\
\hline & null & & 265.39 [225.58-305.39] & & $102.33[80.02-137.13]$ \\
\hline \multirow[t]{8}{*}{ Alcornocales } & Quercus suber & & & & \\
\hline & GSF & EXP & 340.10 [279.69-396.29] & $0.014[0.015-0.018]$ & 277.55 [216.49-369.14] \\
\hline & K & LIN & $443.62[310.38-574.67]$ & $0.58[-0.07$ to 1.23$]$ & $353.74[275.92-470.48]$ \\
\hline & null & & $552.41[419.83-684.79]$ & & $356.25[278.08-476.25]$ \\
\hline & Quercus canariensis & & & & \\
\hline & max. comp. & LIN & 1063.70 [1322.41-784.95] & $-76.28[-124.67$ to -10.55$]$ & 336.02 [276.45-405.66] \\
\hline & null & & 670.36 [549.70-796.85] & & 359.44 [287.74-465.07] \\
\hline & $\begin{array}{l}\text { Quercus pyrenaica } \\
\text { null }\end{array}$ & & 340.50 [299.64-383.91] & & 108.26 [84.64-145.07] \\
\hline
\end{tabular}

Note: the equations for the different models in the table are:

Null model $Y=a+\varepsilon$.

Linear model $\mathrm{Y}=\mathrm{a}+\mathrm{b} \times$ abiotic factor $+\varepsilon$.

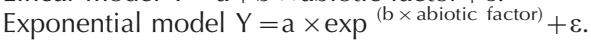


